\title{
Formalism and Realism in Commerce Clause Jurisprudence
}

\author{
Barry Cushman $\dagger$
}

This Article attempts a reconceptualization of developments in Commerce Clause jurisprudence between the Civil War and World War II by identifying ways in which that jurisprudence was structurally related to and accordingly deeply influenced by the categories of substantive due process and dormant Commerce Clause doctrine. Antecedent dormant Commerce Clause jurisprudence set the terms within which Commerce Clause doctrine was worked out; coordinate developments in substantive due process doctrine set limits upon the scope of Commerce Clause formulations and thus played a critical and underappreciated role in maintaining the federal equilibrium. The subsequent erosion of those due process limitations vastly expanded federal power and prompted a crisis in Commerce Clause jurisprudence that was ultimately resolved by adoption of a political process approach to both affirmative and dormant Commerce Clause adjudication. The categories that had unified affirmative and dormant Commerce Clause jurisprudence were abandoned, decoupling the two lines of doctrine and rendering them no longer developmentally interdependent. The two lines went their separate ways, economic substantive due process disappeared, and the enterprise of interdoctrinal coordination that had held a vast body of constitutional law together was lost to history.

We continue to study the development of these lines of doctrine in our Constitutional Law curricula, but we do so in an ahistorical manner that obscures understanding. We study the development of doctrine topically rather than synchronically, wresting lines of doctrine from the related doctrinal contexts in which they developed. Such decontextualization, in this case as in others, is a surefire method of making the entire undertaking look preposterous. Looking back at this jurisprudence from the vantage and through the categories of our contemporary constitutional sensibility, it becomes difficult to understand how any intelligent person could ever have taken the enterprise seriously. Yet a very great many clearly did. This piece seeks to understand why and how that could have been, while at the same time explaining why the enterprise unraveled in the way it did when it did. What emerges, I hope, is a new way of thinking and teaching about constitutional development in this critical period.

\section{INTRODUCTION}

Exegesis of the principal Commerce Clause cases decided by the Supreme Court between 1895 and 1942 typically proceeds with the aid of two rough and ready organizational rubrics: "formalism" and "realism." As one leading casebook puts it, "The cases invoked two general approaches. Under the formal approach, the Court examined the statute and the regulated activity to determine whether certain objective criteria are satisfied.... In contrast, the realist approach attempted to determine the actual economic impact of the regulation." Formalism

$\dagger$ Elizabeth D. \& Richard A. Merrill Research Professor, University of Virginia School of Law. Thanks to Patrice Cushman, Joel Goldstein, John C. Harrison, Roderick Hills, Michael Klarman, Daryl Levinson, Charles McCurdy, Mark Tushnet, and G. Edward White for helpful comments, and to Jason Tilly, Scott Matthews, and Charles Stormont for valuable research assistance.

Geoffrey R. Stone, et al, Constitutional Law 195 (Aspen 3d ed 1996). Though my treatment of the Stone text's handling of these cases is often critical, I should disclose that I use and in most other respects admire the casebook. 
required that the relationship between the local activity and interstate commerce be "formal" and "logical," while the more "pragmatic" realism focused on the "realistic," "practical," "empirical" economic impact. ${ }^{2}$

The exemplar of the formalist approach is United States $v$ E.C. Knight $\mathrm{Co}^{3}$ in which the Court rejected a Sherman Act challenge to a transaction through which the American Sugar Refining Company had acquired four independent refineries and thereby secured control over 98 percent of the refining capacity in the country. In a lonely dissent, Justice Harlan bemoaned the economic consequences that such mergers held for consumers in the interstate market, but the majority would have none of it. ${ }^{4}$ Federal authority did not extend to the control of corporate consolidation in the manufacturing sector, the Court held. Congress had power to regulate commerce among the several states, but not domestic concerns such as mining, agriculture, and manufacturing. Such activities affected interstate commerce, to be sure, but they did so only "indirectly." "Commerce succeeds to manufacture," wrote Chief Justice Fuller, "and is not part of it.",

The principal illustrations of the contrasting "realist" approach are the Shreveport Rate Case and the "stream of commerce" cases. In Shreveport, the Court upheld federal regulation of rates for rail transport between points within a state - what appeared to be a purely "local" activity-on the ground that they bore a "close and substantial" relationship to interstate commerce.' The Justices similarly approved congressional supervision of "local" transactions in public stockyards because they were located in a "current" or "stream" of interstate commerce.

2 See, for example, id at 198, 213, 226; Gerald Gunther and Kathleen M. Sullivan, Constitutional Law 163, 165-66, 168, 185 (Foundation 1997). Here and throughout this article I use the terms "formalism" and "realism" as they are used in the sources cited, without any attempt further to define or defend them.

3156 US 1 (1895).

4 Id at 21-23.

5 Id at 12. The definitive study locating the Knight decision in its immediate jurisprudential context is Charles McCurdy, The Knight Sugar Decision of 1895 and the Modernization of American Corporation Law, 1869-1903, 53 Bus Hist Rev 304 (1979) (arguing that the Sherman Act was framed and Knight decided against a backdrop of an established regime of state control of corporate consolidation in the manufacturing sector). Compare Edward Corwin, The Commerce Power versus States Rights 156 (Princeton 1936) ("[T] he term 'indirect' in this context is a mere device, a formula pulled out of the judicial hat.").

6 Houston, East and West Texas Railway Co v United States, 234 US 342 (1914).

7 Id at 351 .

8 See Tagg Brothers \& Moorhead v United States, 280 US 420, 436-37 (1930) (permitting regulation of livestock market agencies); Stafford $v$ Wallace, 258 US 495, 519 (1922) (permitting Congress to regulate transaction fees charged by intrastate packers and market agents); Swift and Co v United States, 196 US 375 (1905) (approving the application of the Sherman Act to intrastate livestock traders). See also Chicago Board of Trade v Olsen, 262 US 1, 33 (1923) (Rely- 
The fact that the Court as an institution and the Justices individually simultaneously embraced two such disparate modes of analyzing questions of federal power presents an interesting question in judicial psychology. How could any serious legal thinker have uttered the "formalistic" nostra of Knight and Carter Coal" out of one side of his mouth while at the same time advocating such "realistic," "practical" approaches out of the other? Diagnoses might run the gamut from cognitive dissonance to schizophrenia, but the apparent tension between the two intellectual styles would in any event suggest some sort of affliction.

Scholars have traditionally resolved this tension by asserting that those who mouthed these formulations had no serious intellectual commitment to them whatsoever. For more than two generations leading constitutional commentators have concurred with pronouncements like Edward Corwin's in 1941:

[P]rior to the New Deal [the Court's] conceptualistic equipment in the field of constitutional law was often such that the Court was able to translate into juridical idiom almost any result which it might decide to be for the best interest of the country; and [ ] this was definitely the situation when the issue of constitutionality arose on the "commerce" clause."

Benjamin Wright agreed that "with the multiplication of judicial interpretations, there has developed a great body of constitutional law which constitutes a stock-pile from which the Court can draw meanings as the need arises. .. . They are so varied as to give to the artisan a broad range of discretion" and concluded that the Commerce Clause decisions of the 1930s "were dictated not by the Constitution but by the economic and political philosophy of the Justices." Robert McCloskey, in his classic work, The American Supreme Court, maintained that

the Constitution forbids those departures from laissez-faire that the Court disapproves, and permits those departures that the Court thinks reasonable and proper. And obviously this is not a legal "rule" in any understandable sense of the word, but a statement of social policy, or rather an assertion of the power to

ing on Stafford, the Court upheld the Grain Futures Act of Sept 21, 1922, Pub L No 331, 42 Stat 998, regulating grain stored temporarily in the Chicago market before being shipped to other states and foreign countries.).

9 Carter v Carter Coal Co, 298 US 238, 307 (1936) (invalidating provisions of the Bituminous Coal Conservation Act of 1935 in part on the ground that they sought to regulate the "local" activity of coal mining, which affected interstate commerce only "indirectly").

10 Edward S. Corwin, Constitutional Revolution, Ltd. 34 (Claremont 1941).

11 Benjamin F. Wright, The Growth of American Constitutional Law 197-99 (Chicago 1942). 
determine it. Under these loose standards the Court can either uphold or overthrow almost any commercial regulation it encounters, depending on whether the judges approve or disapprove the economic policy the law represents. ${ }^{12}$

A legion of other scholars has followed the lead of these giants, ${ }^{13}$ and their vision dominates our understanding of Commerce Clause development to this day.

Consider, for example, the narrative woven by a leading casebook. It suggests that the Court failed to develop "commerce power doctrine of adequate integrity during the pre-1937 era."14 Instead, "the Court pursued a wavering course, from the restrictive interpretation of Knight to the more generous one of Shreveport." "The doctrinal approaches of these cases cast significant, and often contradictory, shadows over subsequent litigation. Thus, when New Deal laws came before the Court in the 1930s, the differing progeny of the Knight and Shreveport cases offered the Justices a choice of standards." "Cases such as Shreveport were encouraging; yet cases like Knight looked the other way. Would the New Deal measures survive judicial scrutiny? There could be no certainty, for 'there was ample authority in the Supreme Court opinions looking both ways."" "The logical nexus, 'direct-indirect' emphasis of Knight ... [left] a legacy of doctrine capable of being invoked in other contexts; and that legacy proved decisive in the early New Deal cases." "Until 1936, the Court drew mainly on the Knight heritage and invalidated major national laws." "But then, just a year later, in the wake of Franklin D. Roosevelt's Court-packing

12 Robert G. McCloskey, The American Supreme Court 149-50 (Chicago 1960).

13 See, for example, Paul R. Benson, Jr., The Supreme Court and the Commerce Clause, 1937-1970 64 (Dunellen 1970) (The direct-indirect formula was "in fact a highly subjective test under which the justices retained wide discretion to base decisions on their personal social and economic philosophies."); Richard Cortner, The Jones \& Laughlin Case 48 (Arizona 1970); Alfred Kelly and Winfred A. Harbison, The American Constitution 736, 745-46 (Norton 4th ed 1970) (discussing the Justices' laissez-faire sympathies); Alpheus Thomas Mason and William M. Beaney, The Supreme Court in a Free Society 94-95, 156-61 (Norton rev ed 1968) (describing the Court as utilizing legal tools to achieve economic ends); Richard Cortner, The Wagner Act Cases 184 (Tenn 1964) (characterizing early Commerce Clause cases as result-driven and difficult to reconcile); Arthur M. Schlesinger, Jr., The Politics of Upheaval 458-67 (Houghton Mifflin 1960); Alpheus Thomas Mason, The Supreme Court from Taft to Warren vii-ix, 38, 123 (LSU 1958) (describing the era as "judicial mayhem"); Samuel Hendel, Charles Evans Hughes and the Supreme Court 63 (King's Crown 1951) ("[C]onceptions of the practical and beneficial, unconscious or avowed, rather than abstract doctrine furnish the surest explanation of the disagreements of the Justices.").

14 Gunther and Sullivan, Constitutional Law at 171 (cited in note 2).

15 Id at 169

16 Id at 163.

17 Id at 177, citing Robert Stern, The Commerce Clause and the National Economy, 19331946, 59 Harv L Rev 645, 646 (1946).

18 Gunther and Sullivan, Constitutional Law at 163-64 (cited in note 2).

19 Id at 163. 
plan of 1937, the Court became more receptive to national economic regulation: the Shreveport heritage was invoked to provide support for that new constitutional direction." "[B] eginning with 1937, the Shreveport approach, more receptive to expansive congressional uses of the commerce power, became central." "[T] port and other railroad cases were to provide useful constitutional underpinnings for the Court's increasingly benign attitude toward national economic regulation that began in 1937."' And then a concluding rhetorical question: "Can any of the decisions be justified as 'principled' - as a decision that rests on 'reasons that in their generality and their neutrality transcend any immediate result that is involved'? Or were those decisions simply willful fiats by a Court majority hostile to reform, as many New Deal critics charged?"23

The conventional presentation of the Court's Commerce Clause decisions thus suggests that the Justices were at best jurisprudentially disoriented and at worst cynically opportunistic. As an alternative to these dark diagnoses, this Article offers the hypothesis that the commitments evidenced by these apparently competing lines of authority were actually parts of an integrated structure of thought and doctrine. Exploration of the common features of these two traditions may help us to understand how they could have been held in the same mind simultaneously. Such an examination will also assist us in understanding how the "realist" tradition gained preeminence in the late 1930s, and why both traditions fell into desuetude shortly thereafter.

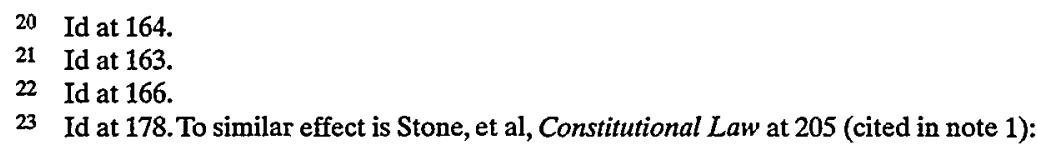

Does the Court's record from the 1880 s to the 1920 s on the issues considered here reflect (a) a principled effort to develop a coherent body of law in an area where determining appropriate doctrine is difficult; (b) an unprincipled effort to uphold laws that enough justices thought wise and to strike down those they thought unwise; (c) an effort to ensure that Congress attend to considerations of federalism by developing a doctrinal repertoire that allowed the Court occasionally to hold a statute unconstitutional? ... Whatever the Court's intentions, by 1930 it had at hand a group of precedents that gave it substantial flexibility in assessing the constitutionality of Congress's efforts to regulate the economy.

See also William Cohen and Jonathan D. Varat, Constitutional Law: Cases and Materials 184-85 (Foundation 10th ed 1997): "[F]rom the beginning of significant congressional regulation of the incidents of nationwide transportation systems and industrial production until 1936, the Court adopted a variety of approaches simultaneously to limit perceived excesses of the commerce power and approve perceived needful uses."

This interpretation of the Court's Commerce Clause doctrine during this era is substantially embraced by Justice Kennedy in his concurrence in United States v Lopez, 514 US 549, 570-74 (1995) (noting the instability of prior Court attempts to distinguish among congressional regulations of the national market), which Cohen and Varat reprint in lieu of narrative exposition. See Cohen and Varat, Constitutional Law at 185-90. 
The Article proceeds as follows. Part I situates the Court's "formalist" affirmative Commerce Clause decisions in the context of the dormant Commerce Clause jurisprudence from which they emerged, and shows how the categories comprising that jurisprudence served important practical goals. Part II locates the Court's "realist" affirmative Commerce Clause decisions in the substantive due process context in which they operated, and shows how "formalist" due process doctrine constrained "realist" Commerce Clause jurisprudence. Part III examines the crisis in Commerce Clause doctrine brought on by the breakdown of these "formalist" due process restraints. Part IV details the manner in which the Court resolved this crisis by reconstructing both dormant and affirmative Commerce Clause doctrine within new conceptual frameworks that cast aside the categories and methods of "formalism" and "realism."

\section{SOME REALISM ABOUT FORMALISM}

\section{A. Formalism and Principle}

First impressions are important. One's first encounter with the distinctions between production and commerce and between direct and indirect effects is usually the Knight opinion, ${ }^{24}$ in which the Court denied the federal government power to abate a monopolistic combination in the manufacturing sector. Read next to Justice Harlan's sensible dissent, the majority opinion appears artificial, wooden, even silly and irresponsible. The need to recognize "the independence of the commercial power and of the police power, and the delimitation between them" ${ }^{25}$ Justice Harlan was prepared to concede. ${ }^{26}$ But he could not assent to a "rigid, technical and narrow" interpretation of the Commerce Clause that placed the federal government "in such a condition of helplessness that it must fold its arms and remain inactive while capital combine [d] ... to destroy competition ... throughout the entire country in the buying and selling of ... the necessaries of life."2s

Yet first impressions can be misleading. As Gunther and Sullivan acknowledge, "The logical nexus, 'direct-indirect' emphasis of Knight, it turned out, did not prove a significant barrier to application of the antitrust laws." ${ }^{29}$ For instance, the Court repeatedly sustained applications of the Sherman Act to interstate railway companies, which were

156 US at 1 .

Id at 13 .

Id at 18, 19 (Harlan dissenting).

Id at 19.

Id at 43.

Gunther and Sullivan, Constitutional Law at 163 (cited in note 2). 
"instruments of commerce, and their business is commerce itself." Such enterprises, engaged in interstate transportation rather than local production, fell on the national side of the local/national dichotomy.

Moreover, the Knight majority had opined that "buying and selling and the transportation incident thereto constitute commerce." This position was elaborated in Addyston Pipe, ${ }^{32}$ where the majority opinion noted:

Where the contract is for the sale of the article and for its delivery in another State, the transaction is one of interstate commerce, although the vendor may have also agreed to manufacture it in order to fulfil his contract of sale. In such case a combination of this character would be properly called a combination in restraint of interstate commerce, and not one relating only to manufacture.

Finding that the pooling agreement of six iron pipe manufactures involved "contracts for the sale and transportation to other States of specific articles," the Court unanimously sustained the government's challenge to the combination's legality. "It is the sale and delivery, of a certain kind and quality of pipe," wrote Justice Peckham, "and not the manufacture, which is the material portion of the contract, and a sale for delivery beyond the State makes the transaction a part of interstate commerce." 35

The Knight Court rested its decision on the absence of evidence that the company intended to restrain interstate commerce. "There was nothing in the proofs," Fuller wrote, "to indicate any intention to put a restraint upon trade or commerce, and the fact, as we have seen, that trade or commerce might be indirectly affected was not enough to entitle complainants to a decree. ${ }^{, 36}$ The implication was of course

30 Northern Securities Co v United States, 193 US 197, 353 (1904). See, for example, United States v Joint Traffic Association, 171 US 505, 568-70 (1898) (invalidating a rate-setting agreement among railroads); United States $v$ Trans-Missouri Freight Association, 166 US 290 (1897) (invalidating another agreement to set intrastate rates). For additional railroad antitrust cases, see Barry Cushman, The Secret Lives of the Four Horsemen, 83 Va L Rev 559, 630 n 78 (1997).

31156 US at 14.

32 Addyston Pipe and Steel Co $v$ United States, 175 US 211 (1899).

33 Id at 246.

34 Id at 240.

35 Id at 242. See also Continental Wall Paper Co v Louis Voight and Sons Co, 212 US 227, 264-65 (1909) (holding that part of agreement that regarded interstate sales brought whole agreement within interstate commerce); Montague \& Co v Lowry, 193 US 38, 45-46 (1904) (holding that tiles that were to be shipped out-of-state constituted objects of interstate commerce).

36 Knight, 156 US at 17 . "The object was manifestly private gain in the manufacture of the commodity, but not through the control of interstate or foreign commerce.... [I]t does not follow that an attempt to monopolize, or the actual monopoly of, the manufacture was an attempt, whether executory or consummated, to monopolize commerce ...." Id (emphasis added). The 
that the case would have been decided differently had intent been shown. And, indeed, when such intent was proven in subsequent cases such as Standard Oil Co $v$ United States ${ }^{37}$ and United States $v$ American Tobacco $\mathrm{Co}^{38}$ the Court did not hesitate to find the Sherman Act applicable. In fact, the government and private plaintiffs enjoyed considerable success before the Court in their attempts to control the behavior of corporate giants with the federal antitrust laws.

The Stone, et al, text, by contrast, offers no similar acknowledgment that the Court ever recognized federal authority in business antitrust cases. The notes following Knight immediately introduce the second Coronado Coal case, in which the Court held that the Sherman Act applied to a labor strike against mine operators. ${ }^{41}$ The text observes that the Court distinguished Coronado Coal from Knight in Carter v Carter Coal, ${ }^{42}$ in which the Court struck down provisions of the Bituminous Coal Conservation Act of 1935 conferring upon the employees of coal producers the right to bargain collectively. The distinction drawn was that in Coronado Coal, "The acts of the persons involved were local in character, but the intent was to restrain interstate commerce, and the means employed were calculated to carry that intent into effect. Interstate commerce was the direct object of attack; and the restraint of such commerce was the necessary consequence of the acts and the immediate end in view." the supply of a good was "ordinarily an indirect and remote obstruction" of interstate commerce, but "when the intent ... [was] to restrain or control the supply" of a good in interstate commerce, the Sherman Act applied. The text then asks whether the distinction between Knight and Coronado Coal is "intelligible," whether Carter Coal "ef-

\footnotetext{
restraint on commerce imposed by a combination in manufacturing, mining, or agriculture "would be an indirect result, however inevitable and whatever its extent, and such result would not necessarily determine the object of the contract, combination, or conspiracy." Id at 16 (emphasis added). "[T] preme Court (Harper 1914), "the case for the Government was not well prepared at the circuit. No direct evidence that the sales of sugar across State lines, and the control of the business of such sales and of prices, were the chief object of the combination was submitted to the Court." Id at 59.

37221 US 1, 74-77 (1911) (finding an intent to control the national oil market).

38221 US 106, 181-83 (1911) (holding that a combination sought to monopolize the national tobacco market).

39 For a sample of such success stories between 1911 and 1940, see Cushman, 83 Va L Rev at 628-30 nn 77-80 (cited in note 30).

40 Coronado Coal Co v United Mine Workers, 268 US 295 (1925) (“Coronado Coal II").

41 Id at 310.

42298 US 238 (1936).

43 Id at 304.

44 Coronado Coal II, 268 US at 310.

45 Stone, et al, Constitutional Law at 198 (cited in note 1).
} 
fectively distinguish[ed] Coronado Coal," and "[i]n light of Coronado Coal, did the Court over the period from 1890 to 1930 have and use a coherent notion of 'good' versus 'bad' regulation?", Juxtaposing only Knight, Coronado Coal and Carter Coal, it would be the extraordinary student who could manage anything other than a power guffaw in response. Obviously, the Court opportunistically manipulated a pile of transparently result-oriented mumbo-jumbo in order to line the pockets of corporate fat cats while putting the screws to organized labor.

A different response might be elicited, however, were the reader aware of the existence of labor case analogues to Knight. Coronado Coal had first come before the Court in 1922. Remarking that "[c]oal mining is not interstate commerce, and the power of Congress does not extend to its regulation as such, ${ }^{, 48}$ the Court unanimously reversed the Sherman Act judgment against the union. Listen to the echoes of Knight in the opinion of Chief Justice Taft:

"The making of goods and the mining of coal are not commerce, nor does the fact that these things are to be afterwards shipped or used in interstate commerce, make their production a part thereof." Obstruction to coal mining is not a direct obstruction to interstate commerce in coal, although it, of course, may affect it by reducing the amount of coal to be carried in that commerce."

In order for the Sherman Act to apply, the Court held, "the intent to injure, obstruct or restrain interstate commerce must appear as an obvious consequence of what is to be done, or shown by direct evidence or other circumstances." ${ }^{\text {so }}$ Here the coal operators had produced no such evidence of intent, and the strike was therefore a local matter outside the federal regulatory bailiwick. ${ }^{\text {s1 }}$

United Leather Workers International Union $v$ Herkert \& Meisel Trunk $\mathrm{Co}^{52}$ decided in 1924, is to the same effect. The union, seeking to obtain a closed shop agreement, had engaged in a strike that concededly was aimed at preventing the manufacture of goods that would have been transported in interstate commerce. The company, however,

46 Id at 213.

47 Id at 199.

48 United Mine Workers v Coronado Coal Co, 259 US 344, 407 (1922) ("Coronado Coal $\left.\Gamma^{\prime \prime}\right)$.

49 Id at 408, quoting in part Hammer v Dagenhart, 247 US 251, 272 (1918).

50 Coronado Coal I, 259 US at 408.

51 Id at 407-13. See Stanley I. Kutler, Chief Justice Taft, Judicial Unanimity, and Labor: The Coronado Case, 24 The Historian 68,72-74 (1961) (indicating that the debate within the Court was over the purpose of the alleged conspiracy). See also Alexander M. Bickel, Unpublished Opinions of Mr. Justice Brandeis 77-99 (Belknap 1957) (discussing Justice Brandeis's draft dissenting opinion in Coronado $I$, in which he argued that the purpose of the conduct was to restrain only the intrastate activity of mining coal).

52265 US 457 (1924). 
produced no evidence that the striking workers had tried to interfere with the sale or transport of the goods once they had been manufactured. ${ }^{\text {s3 }}$ Simply hoping that a decline in sales would bring management around did not render the union subject to Sherman Act discipline. Nor did it matter that the workers had engaged in acts of illegal picketing and intimidation in order to achieve their aim. Again employing the Knight categories, the Court unanimously rebuffed the company's claim.

[T] he mere reduction in the supply of an article to be shipped in interstate commerce, by the illegal or tortious prevention of its manufacture, is ordinarily an indirect and remote obstruction to that commerce. It is only when the intent or necessary effect upon such commerce in the article is to enable those preventing the manufacture to monopolize the supply, control its price or discriminate as between its would-be purchasers, that the unlawful interference with its manufacture can be said directly to burden interstate commerce. ${ }^{s 4}$

A third case, this one decided in 1933, again illustrates the Court's persistent, principled adherence to the Knight formulation. In Levering \& Garrigues Co v Morrin, ${ }^{s s}$ the Court unanimously refused to enjoin a boycott for a closed shop at a company engaged in the business of fabricating and erecting structural steel for shipment in interstate commerce. ${ }^{56}$ The boycott may have reduced or eradicated the company's interstate business, but that was just tough luck. Again focusing on the question of intent, the Court found that "the sole aim of the conspiracy was to halt or suppress local building operations as a means of compelling the employment of union labor, not for the purpose of affecting the sale or transit of materials in interstate commerce."

Use of the materials was purely a local matter, and the suppression thereof the result of the pursuit of a purely local aim. Restraint of interstate commerce was not an object of the conspiracy. ... Prevention of the local use was in no sense a means adopted to effect such a restraint. It is this exclusively local aim, and not the fortuitous and incidental effect on interstate commerce, which gives character to the conspiracy. If thereby the

\footnotetext{
53 Id at 464.

54 Id at 471.

55289 US 103 (1933).

56 Id at 106-07.

57 Id at 107.
} 
shipment of steel in interstate commerce was curtailed, that result was incidental, indirect and remote. ${ }^{58}$

These were of course not the remarks of a Court in the pocket of organized labor. Conservative justices felt the pinch of "formalism." As Taft put it in his first Coronado Coal opinion, "[T]he circumstances [which involved homicide and arson] are such as to awaken regret that, in our view of the federal jurisdiction, we cannot affirm the judgment. But it is of far higher importance that we should preserve inviolate the fundamental limitations in respect to the federal jurisdiction." Justice Day, the author of Hammer v Dagenhart, "wrote on his return of Taft's circulated opinion, "I agree, and regret that this gross outrage by the local union cannot be reached by federal authority." Justice McReynolds was more blunt. On his return of the opinion he wrote simply, "I am sorry you can't make the scoundrels pay."

B. Formalism as Consequentialism

1. Preserving federalism.

But the fact that the categories of "formalism" were deployed in a more evenhanded fashion than we have been prepared to recognize will not alone rebut the charge that "formalism" was a peculiarly mindless form of nominalism..$^{63}$ For this it is necessary to recognize that "formalism" was itself rooted in consequentialist concerns. There are two senses in which such a claim might be made for formalism. First, the division of the world into local and national spheresplacing manufacturing, mining, agriculture, and other productive industry in the local sphere, while locating interstate transportation, as well as sales and negotiations of sales for subsequent interstate shipment, in the national-was itself a conscious strategy for circumscribing the boundaries of national and local competence in a principled fashion. Justice Cardozo would later suggest in his Schechter concurrence $^{64}$ (and Chief Justice Hughes would agree in his opinion for the Court in Jones \& Laughlin) ${ }^{65}$ that the Justices should make case-by-

58 Id.

59 Coronado Coal 1,259 US at 413.

60247 US 251 (1918) (striking down a regulation prohibiting the shipment in interstate commerce of goods manufactured by child labor).

61 Papers of William Howard Taft, Reel 615.

62 Id. On his return Justice Pitney remarked wryly, "Too true to be good." Id.

63 Here I use the term "nominalism" to denote a preoccupation with the name; for example, "manufacturing" of the activity regulated, rather than the consequences of the activity or its regulation.

64 A.L.A. Schechter Poultry Corp v United States, 295 US 495, 554 (1935) ("The law is not indifferent to considerations of degree.").

65 NLRB v Jones \& Laughlin Steel Corp, 301 US 1, 37 (1937) ("The question [of effect on 
case calls concerning whether a local activity affected interstate commerce sufficiently to warrant federal regulation. Whether anything that could be called a rule of law could emerge from such an enterprise is an interesting question; the Court so quickly abandoned this approach that we may never know the answer. ${ }^{\infty}$ But the Justices of the "formalist" period clearly thought not, as their insistence on reasoning in a "parade of horribles" style made clear. Listen again to Knight:

If it be held that the term [commerce] includes the regulation of all such manufactures as are intended to be the subject of commercial transactions in the future, it is impossible to deny that it would also include all productive industries that contemplate the same thing. The result would be that Congress would be invested, to the exclusion of the States, with the power to regulate, not only manufactures, but also agriculture, horticulture, stock raising, domestic fisheries, mining -in short, every branch of human industry.

That is, there would be no principled point at which to draw the line beyond which federal authority might not venture. Federal power would perforce be plenary. A situation "less likely to have been what the framers of the Constitution intended," Fuller maintained, "would be difficult to imagine."

This view was reiterated in Schechter by the author of Shreveport himself. Defending the distinction between direct and indirect effects on commerce, Chief Justice Hughes wrote:

If the commerce clause were construed to reach all enterprises and transactions which could be said to have an indirect effect upon interstate commerce, the federal authority would embrace practically all the activities of the people and the authority of the State over its domestic concerns would exist only by sufferance of the federal government.

The Government's argument in favor of the Live Poultry Code's regulation of wages and hours in local slaughterhouses, Hughes maintained,

proves too much. If the federal government may determine the wages and hours of employees in the internal commerce of a State, because of their relation to cost and prices and their indirect effect upon interstate commerce, it would seem that a similar

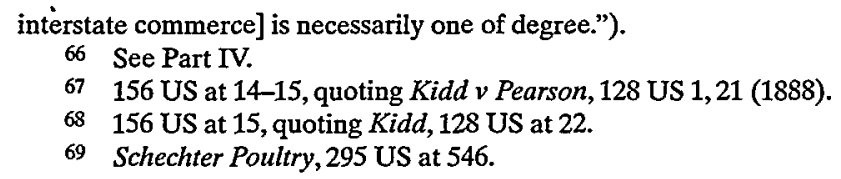

69 Schechter Poultry, 295 US at 546. 
control might be exerted over other elements of cost, also affecting prices, such as the number of employees, rents, advertising, methods of doing business, etc. All the processes of production and distribution that enter into cost could likewise be controlled. If the cost of doing an intrastate business is in itself the permitted object of federal control, the extent of the regulation of cost would be a question of discretion and not of power. ${ }^{70}$

"It is not the province of the Court to consider the economic advantages or disadvantages of such a centralized system," Hughes concluded. "It is sufficient to say that the Federal Constitution does not provide for it."

\section{Promoting free trade while preserving the powers to tax} and regulate.

But the Justices who had forged the categories to which Hughes and his colleagues would later cling had in fact considered the economic advantages and disadvantages of such a centralized system, and this brings us to the second sense in which "formalism" was itself a consequentialist jurisprudence. In the late nineteenth and early twentieth centuries, the central question in constitutional federalism was not the extent to which the Commerce Clause empowered Congress to regulate local activities. It was instead the degree to which the "negative implications" of that clause limited the regulatory authority of state and local governments. ${ }^{n}$ As the national economy became increasingly integrated in the years following the Civil War, the Court began a conscious and increasingly aggressive campaign to break down local barriers to interstate trade through a "free-trade" construction of the dormant Commerce Clause. ${ }^{73}$ In the process the Court

70 Id at 549.

71 Id.

72 A fact abundantly illustrated by a review of the Commerce Clause treatise literature of the period, in which treatments of dormant Commerce Clause decisions simply dwarf corresponding exegesis of affirmative Commerce Clause jurisprudence. See, for example, F.D.G. Ribble, State and National Power Over Commerce (Columbia 1937); Bernard C. Gavit, The Commerce Clause (Principia 1932); Frederick N. Judson, The Law of Interstate Commerce and Its Federal Regulation (T.H. Flood 2d ed 1912); Frederick H. Cooke, The Commerce Clause (Baker 1908); Thomas H. Calvert, Regulation of Commerce under the Federal Constitution (Thompson 1907); Paul Jones, The Commercial Power of Congress (1904); E. Parmalee Prentice and John G. Egan, The Commerce Clause of the Federal Constitution (Callaghan 1898); William Draper Lewis, The Federal Power over Commerce and Its Effects on State Action (Pennsylvania 1892).

73 "[P]owerful economic forces ... [i] ndustrialization and improvement in transportation facilities, with an accompanying extension of trade horizons, demanded the freedom from state regulation of commerce ...." The "effect was to cause [the] grant of power to be interpreted as generally exclusive by the Supreme Court." Joseph E. Kallenbach, Federal Cooperation with the States under the Commerce Clause 31 (Greenwood 1968). 
substantially curtailed such time-honored local regulations ${ }^{74}$ as discriminatory license taxes on those selling out-of-state goods ${ }^{75}$ and discriminatory taxes on the out-of-state goods themselves. "In granting to Congress the right to regulate commerce ... among the several States," Justice Miller explained, "the framers of the Constitution believed that they had sufficiently guarded against the dangers of any taxation by the States which would interfere with the freest interchange of commodities among the people of the different States." Upholding such discriminatory taxation would lead to "a total abolition of all commercial intercourse between the States." The Constitution "had its immediate origin in the necessities of commerce; and for its immediate object ... establishing a uniform and steady system." Such protectionist legislation, wrote Justice Harlan,

if maintained by this court, would ultimately bring our commerce to that "oppressed and degraded state," existing at the adoption of the present Constitution, when the helpless, inadequate Confederation was abandoned and a national government instituted . ... The concession of such a power to the State would render wholly nugatory all national control of commerce among the States, and place the trade and business of the country at the

74 See Charles Fairman, 7 History of the Supreme Court of the United States: Reconstruction and Reunion, 1864-88, Part II 666 (New York 1987); McCurdy, The Knight Sugar Decision at 309-11 (cited in note 5).

75 See, for example, Bethlehem Motors Corp v Flynt, 256 US 421, 426-27 (1921) (invalidating a state licensing requirement that disproportionately burdened dealers in automobiles manufactured outside the state); Walling $v$ Michigan, 116 US 446 (1886) (holding that a tax imposed by a state upon liquor salespeople that necessarily discriminated against the introduction of products of another state was unconstitutional); Webber $v$ Virginia, 103 US 344, 350-51 (1880) (invalidating a state statute requiring agents dealing in articles manufactured in other states to obtain a license); Tiernan $v$ Rinker, 102 US 123 (1880) (holding that a person cannot be subjected to a higher state tax for the right to sell imported rather than domestic liquor); Morrill $v$ Wisconsin, 154 US 626 (1877) (following Welton); Welton v Missouri, 91 US 275, 279 (1876) (striking down a state statute that required licenses of those who sold items "which are not the growth, produce, or manufacture" of the state); Ward $v$ Maryland, 79 US (12 Wall) 418, 431-32 (1870) (striking down a discriminatory state statute requiring all dealers in imported articles to be licensed by the state).

76 See, for example, I.M. Darnell \& Son Co v City of Memphis, 208 US 113, 121 (1908) (prohibiting differentiation in state taxation between property coming to rest within a state and property produced within a state); Charles K. Burdick, The Law of the American Constitution: Its Origin and Development 249 (Putnam 1922) (noting that the Commerce Clause limits states to only those taxes that treat the products of interstate commerce equally to those of intrastate commerce).

77 Cook v Pennsylvania, 97 US 566, 574 (1878) (emphasis added) (invalidating a discriminatory state tax on sales made by auctioneers of goods imported from other states in their original packages).

78 Hinson $v$ Lott, 75 US (8 Wall) 148, 152 (1868) (Miller) (upholding a state flat tax on liquor).

79 Guy v Baltimore, 100 US 434, 440 (1879) (invalidating a municipal ordinance establishing discriminatory wharfage rates based on the origin of cargo of vessels). 
mercy of local regulations, having for their object to secure exclusive benefits to the citizens and products of particular States.

The Court similarly struck down state inspection laws that discriminated against out-of-state goods ${ }^{81}$ or imposed inspection fees that the Justices deemed unreasonable. In striking down a Minnesota statute requiring all meat sold in the state to be inspected on the hoof within twenty-four hours before slaughter, Justice Harlan feared that "the enactment of a similar statute by each one of the States composing the Union would result in the destruction of commerce among the several States" in meat."

Nor did the Court stop at invalidating such patently discriminatory trade barriers. Even nondiscriminatory impediments to interstate trade withered beneath the Court's exacting scrutiny. Among the more conspicuous decisions were those in which the Court compromised the states' powers of internal police by denying them the authority to exclude from their borders such controversial products as liquor, oleomargarine, ${ }^{84}$ and cigarettes. ${ }^{84}$ As Justice Matthews wrote in

80 Id at $440-42$.

81 See, for example, Voight $v$ Wright, 141 US 62,66-67 (1891) (invalidating flour inspection law that required examination of only out-of-state flour); Brimmer v Rebman, 138 US 78, 84 (1891) (striking down a meat inspection statute that required meat processed more than one hundred miles from the place of sale to be reinspected).

82 See, for example Phipps v Cleveland Refining Co, 261 US 449, 452 (1923) (holding an "excessive" petroleum inspection fee to be an invalid burden on interstate commerce); Standard Oil Co v Graves, 249 US 389,396-97 (1919) (invalidating a revenue-generating inspection fee on petroleum); D.E. Foote \& Co v Stanley, 232 US 494, 507 (1914) (holding that an inspection fee on out-of-state products is unconstitutional if it exceeds the costs of inspection).

83 Minnesota v Barber, 136 US 313, 321 (1890).

84 See, for example, Rosenberger v Pacific Express Co, 241 US 48 (1916) (holding that state law imposing special licenses on express companies maintaining offices for C.O.D. shipments of liquor was unconstitutional as applied to interstate shipments); Rossi v Pennsylvania, 238 US 62 (1916) (narrowly construing congressional statute permitting state regulation of liquor at place of sale not to apply to interstate shipments); Kirmeyer $v$ Kansas, 236 US 568, 573 (1915) (invalidating prohibition on interstate liquor wagon traffic); Louisville \& Nashville Railroad Co v FW. Cook Brewing Co, 223 US 70, 82-83 (1912) (holding prohibition on shipment of liquor to parts of state unconstitutional as applied to interstate shipments); Adams Express Co v Kentucky, 214 US 218, 223 (1909) (invalidating state prohibtion on the shipping of liquor); Adams Express Co $v$ Kentucky, 206 US 129, 138 (1907) (invalidating Kentucky statute punishing shipments of liquor to be paid for on delivery); American Express Co v Iowa, 196 US 133,146 (1905) (holding unconstitutional a state's seizure of liquor shipped in interstate commerce); Vance $v$ W.A. Vandercook $C o, 170$ US 438 (1898) (striking down a state law requiring that any liquor imported from other states first be certified pure by the state chemist); Scott $v$ Donald, 165 US 58, 101 (1897) (invalidating statute regulating the use, sale, and transportation of liquor); Lyng v Michigan, 135 US 161,166 (1890) (invalidating state tax on liquor imported through interstate commerce because "no state has the right to lay a tax on interstate commerce in any form"); Leisy v Hardin, 135 US 100,125 (1890) (invalidating prohibition on sale of liquor as applied to liquor imported from another state). See also Heymen v Southern Railway Co, 203 US 270 (1906) (invalidating a state liquor regulation); Rhodes $v$ Iowa, 170 US 412, 426 (1898) (invalidating a state law banning the transportation of liquor in trucks, over a vigorous dissent).

85 See Collins $v$ New Hampshire, 171 US 30 (1898) (striking down statute forbidding sale of 
invalidating an Iowa statute requiring all carriers to obtain state certification before transporting liquor into the state:

Can it be supposed that by omitting any express declarations on the subject, Congress has intended to submit to the several States the decision of the question in each locality of what shall and what shall not be articles of traffic in the interstate commerce of the country? If so, it has left to each State, according to its own caprice and arbitrary will, to discriminate for or against every article grown, produced, manufactured, or sold in any State and sought to be introduced as an article of commerce into any other. If the State of Iowa may prohibit the importation of intoxicating liquors from all other States, it may also include tobacco, or any other article, the use or abuse of which it may deem deleterious.... It may choose to establish a system directed to the promotion and benefit of its own agriculture, manufactures or arts of any description, and prevent the introduction and sale within its limits of any or all articles that it may select as coming into competition with those which it seeks to protect.... In view of the commercial anarchy and confusion that would result from the diverse exertions of power by the several States of the Union, it cannot be supposed that the Constitution or Congress have intended to limit the freedom of commercial intercourse among the people of the several States.

At the same time the Court similarly struck down state enactments regulating the operations of interstate carriers, ${ }^{88}$ prescribing the

oleomargarine unless it was colored pink); Schollenberger v Pennsylvania, 171 US 1,24-25 (1898) (invalidating state statute prohibiting the sale, in the original package, of uncolored oleomargarine). Plumley v Massachusetts, 155 US 461, 467-68 (1894), however, upheld a state prohibition on importation of oleomargarine colored to look like butter on a consumer fraud rationale. Similarly, Crossman v Lurman, 192 US 189, 209 (1904), upheld a state statute prohibiting the sale in the state of artificially colored coffee, and Silz $v$ Hesterberg, 211 US 31 (1908), upheld a state act prohibiting importation of foreign game in order to protect its own game supply.

86 Austin v Tennessee, 179 US 343, 359 (1900) (suggesting in dicta that a state could not prohibit the interstate sale and transportation of cigarettes in original packages). See also concurring opinion of Justice White, 179 US at 363 (finding nothing in majority opinion abandoning the "original package" doctrine), and cissenting opinion of Justice Brewer, 179 US at 364 (arguing that the power to regulate interstate shipment of cigarettes does not extend to states). See Thomas A. Sims, The Constitutionality of the Indiana Anti-Cigarette Law, 4 Mich L Rev 124, 134, 137 (1905) (discussing the limits of the "original package" rule); Gavit, The Commerce Clause at 128 (cited in note 72) ("The rule can be stated to be that provided goods which have been transported in interstate commerce are not diseased or misrepresented they may be sold in the original package as against a state total prohibition of the sale."); Burdick, The Law of the American Constitution at 246 (cited in note 76) ("[A] State may not prohibit the shipment into or out of its borders of goods which are the legitimate subject of commerce.").

87 Bowman v Chicago and Northwestern Railway Co, 125 US 465, $493-94$ (1888).

88 The Court repeatedly struck down state licensing statutes applying to interstate carriers. See, for example, Mayor and Board of Aldermen of the Town of Vidalia $v$ McNeely, 274 US 676 
prices of goods sold in interstate commerce, ${ }^{59}$ and taxing goods moving in interstate commerce. ${ }^{90}$ If the power to tax such commerce were con-

(1927) (holding that a state may not require a license as a condition precedent to operating an interstate ferry route); Barrett $v$ City of New York, 232 US 14, 33 (1914) (striking down a state licensing requirement for interstate carriers as directly burdening interstate commerce); St. Clair County v Interstate Sand and Car Transfer Co, 192 US 454, 467-69 (1904) (invalidating a usage tax imposed on vessels crossing a state boundary); Harmon v City of Chicago, 147 US 396 (1893) (striking down a municipal license tax imposed for the privilege of navigating the Chicago River); Crutcher $v$ Kentucky, 141 US 47,61 (1891) (invalidating a state licensing requirement for agents of foreign railway companies); Norfolk and Western Railroad Co v Pennsylvania, 136 US 114 (1890) (striking down a state tax levied on a railroad for the privilege of maintaining an office within the state); McCall v California, 136 US 104 (1890) (holding a California license tax levied upon an agent of a railway soliciting business for a route between Chicago and New York unconstitutional); Pickard v Pullman Southern Car Co, 117 US 34 (1886) (invalidating license tax on sleeping cars). See also Gavit, The Commerce Clause at $350 \& \mathrm{n} 27$ (cited in note 72), and cases therein cited.

State efforts to fix rates for interstate carriage were similarly struck down. See, for example, Baltimore \& Ohio Southwestern Railroad Co v Settle, 260 US 166 (1922) (invalidating regulation of prices for interstate transport); Railroad Commission of Ohio $v$ Worthington, 225 US 101 (1912) (striking down a rate-fixing regulation as applied to goods destined for export to other states); Louisville \& Nashville Railroad Co v Eubank, 184 US 27, 41-42 (1902) (invalidating a state requirement mandating cheaper rates for shorter routes insofar as it sought to regulate interstate commerce); Covington \& Cincinnati Bridge Co v Kentucky, 154 US 204 (1894) (invalidating state efforts to fix a toll for the use of a boundary crossing bridge); Wabash, St. Louis \& Pacific Railway Co $v$ Illinois, 118 US 557, 576 (1886) (invalidating a state rate requirement as applied to goods transported outside of the state). Nor would the Court permit states to prescribe the locations at which interstate trains made stops. See, for example, Illinois Central Railroad Co $v$ Illinois, 163 US 142 (1896). States could not order removal of a bridge used in interstate transportation, Kansas City Southern Railway Co v Kaw Valley Drainage District, 233 US 75 (1914); nor could they regulate the speed of interstate trains, Seaboard Air Line Railway Co v Blackwell, 244 US 310 (1917); nor could they regulate the schedules of interstate trains, Missouri, Kansas \& Texas Railway Co v Texas, 245 US 484 (1918); nor could they require interstate carriers to obtain certificates of necessity before using state highways, Buck v Kuykendall, 267 US 307, 315 (1925); George W. Bush \& Sons Co v Maloy, 267 US 317 (1925); nor could they impose the "direct" burden of requiring an interstate railroad to deliver cars to a private siding, McNeill $v$ Southern Railway Co, 202 US 543, 561 (1906); nor could they require interstate carriers to furnish a certain number of cars for interstate transport on a specified day, Houston \& Texas Central Railroad Co $v$ Mayes, 201 US 321, 330-31 (1906). Similarly, the Court disapproved state attempts to regulate the transmission and receipt of interstate messages by telegraph companies. See Western Union Telegraph Co v Foster, 247 US 105 (1918) (invalidating law requiring firm to accept all wire stock quotes); Western Union Telegraph Co v Pendleton, 122 US 347 (1887) (striking down law requiring telegraph operators to hand deliver messages).

89 See, for example, Public Utilities Commission of Rhode Island v Attleboro Steam \& Electric Co, 273 US 83, 89 (1927) (invalidating a state's regulation of rates charged for electric current delivered to neighboring states); Missouri v Kansas Natural Gas Co, 265 US 298, 308-09 (1924) (striking down a state attempt to fix the rates of natural gas piped out of the state); Lemke $v$ Farmers Grain Co, 258 US 50 (1922) (invalidating a state law imposing a licensing fee on grain buyers, substantial regulation of grain elevators, and price controls on grain produced for export to other states as an unconstitutional burden on interstate commerce).

90 See, for example, Eureka Pipe Line Co v Hallanan, 257 US 265, 271 (1921) (invalidating a state tax on oil temporarily stored prior to its transport out of the state); Kelley $v$ Rhoads, 188 US 1,8-9 (1903) (exempting from application of a state tax certain sheep being driven through the taxing state); Western Union Telegraph Co $v$ Pennsylvania, 128 US 39, 39-40 (1889) (holding unconstitutional state laws levying a tax on the transmittal of messages beyond the borders of the state); Fargo v Michigan, 121 US 230, 243-47 (1887) (invalidating gross receipts tax on rail- 
ceded, opined Justice Strong, then the tax might be made "so onerous that an interchange of commodities with other States would be rendered impossible." Maintaining that all negotiations for sales of tangible goods to be shipped across state lines were themselves interstate commerce, the Court repeatedly invalidated state and local efforts to license or tax those soliciting or transacting such interstate business."

road carrying freight and passengers into, out of, or through the state); Reading Railroad Co $v$ Pennsylvania ("State Freight Tax Case"), 82 US (15 Wall) 232, 281-82 (1873) (striking down a per pound state tax on freight). See also State Freight Tax Case, 82 US (15 Wall) at 299 (Miller dissenting in part) (Full recognition of the principle that states cannot tax interstate commerce "is essential to the harmonious future of this country.... The interstate commerce to-day far exceeds in value that which is foreign, and it is of immense importance that it should not be shackled by restrictions imposed by any State in order to place on others the burden of supporting its own government, as was done in the days of the helpless Confederation.").

91 State Freight Tax Case, 82 US (15 Wall) at 276. "[I]f one State can directly tax persons or property passing through it, or tax them indirectly by levying a tax upon their transportation, every other may, and thus commercial intercourse between States remote from each other may be destroyed. The produce of the Western States may thus be effectually excluded from Eastern markets, for though it might bear the imposition of a single tax, it would be crushed under the load of many. It was to guard against the possibility of such commercial embarrassments, no doubt, that the power of regulating commerce among the States was conferred upon the Federal Government." Id at 280.

92 See, for example, Pacific Telephone \& Telegraph Co $v$ Tax Commission, 297 US 403, 41213 (1936) ("While a State may tax the privilege of engaging in local business ... it may not tax the privilege of engaging in interstate commerce."); Real Silk Hosiery Mills $v$ Portland, 268 US 325, 335-36 (1925) (striking down a license tax on solicitors of orders to be filled by an out-ofstate manufacturer); Shafer v Farmers Grain Co, 268 US 189,199 (1925) (striking down a license requirement for the purchase of grain within a state where the grain sold was to be immediately shipped out of the state); Texas Co v Brown, 258 US 466, 475-77 (1922) (striking down a Georgia inspection fee for oil and gasoline as applied to products still in interstate commerce); DahnkeWalker Milling Co v Bondurant, 257 US 282, 290-92 (1921) (invalidating state conditions on the conduct of foreign corporations as applied to purchase of domestic wheat to be shipped outside the state); Bowman $v$ Continental Oil Co, 256 US 642, 646-47 (1921) (invalidating a state privilege tax as applied to the interstate component of the business, which was gasoline imported from out of state); Askren v Continental Oil Co, 252 US 444, 447 (1920) (striking down a state privilege tax as applied to distributors bringing gasoline in from outside the state for sale within the state); York Manufacturing Co $v$ Colley, 247 US 21, 23-26 (1918) (holding that employment of a non-resident engineer by a Pennsylvania corporation engaged in the construction of an icemaking plant in Texas did not involve the doing of local business subject to state regulation); Crew Levick Co v Pennsylvania, 245 US 292, 296-97 (1917) (invalidating a state privilege tax as applied to the interstate component of the corporation's business); Western Oil Refining Co $v$ Lipscomb, 244 US 346, 349-50 (1917) (invalidating a privilege tax where imposed on a foreign corporation delivering oil to customers within the taxing state); Cheney Brothers Co v Massachusetts, 246 US 147, 155-56 (1916) (invalidating an excise tax on foreign corporations engaged in solicitation of orders subject to the home office's approval); Stewart v Michigan, 232 US 665, 670 (1914) (striking down a state statute requiring a license for catalogue sales); Crenshaw v Arkansas, 227 US 389, 399-401 (1913) (striking down a state law requiring a foreign corporation actively soliciting sales within the taxing state to obtain a license); Dozier v Alabama, 218 US 124, 127-28 (1910) (striking down a licensing requirement imposed on the solicitors of photography enlargement services and frames manufactured in another state); International Textbook Co $v$ Pigg, 217 US 91, 107 (1910) (holding unconstitutional a state statute requiring an educational publishing company to pay a license fee for sending and receiving correspondence); Rearick $v$ Pennsylvania, 203 US 507, 510-11 (1906) (striking down a municipal licensing requirement for the solicitation of orders for goods manufactured in another state); Norfolk and Western Railway 
In striking down a local tax on drummers, the Court noted that " $[\mathrm{t}]$ his kind of taxation is usually imposed at the instance and solicitation of domestic dealers, as a means of protecting them from foreign competition." If a state were thus permitted to "impose restrictions upon interstate commerce for the benefit and protection of its own citizens," wrote Justice Bradley in an opinion suffused with consequentialist analysis, "we are brought back to the condition of things which existed before the adoption of the Constitution, and which was one of the principal causes that led to it." If regulation of drummers were desirable, Congress alone could provide it. For it was

obvious that such regulations should be based on a uniform system applicable to the whole country, and not left to the varied, discordant, or retaliatory enactments of forty different states. The confusion into which the commerce of the country would be thrown by being subject to state legislation on this subject, would be but a repetition of the disorder which prevailed under the Articles of Confederation."

The Court's use of the dormant Commerce Clause to vitiate such parochial legislation played a critical, instrumental role in opening a national market." As Charles Warren remarked of one leading decision, its effect "upon the development of the great transcontinental trade,

Co $v$ Sims, 191 US 441, 449-51 (1903) (invalidating a state licensing requirement imposed on an express company acting as an agent of the dealer for the importation of a sewing machine); Atlantic and Pacific Telegraph Co v Philadelphia, 190 US 160, 162 (1903) ("No State can compel a party, individual or corporation to pay for the privilege of engaging in interstate commerce."); Caldwell v North Carolina, 187 US 622 (1903) (striking down a municipal ordinance taxing persons engaged in the business of selling photographs as applied to a representative of a firm residing outside of the state); Stockard v Morgan, 185 US 27,36-37 (1902) (following Brennan); Brennan $v$ Titusville, 153 US 289, 306-08 (1894) (striking down a licensing tax on persons engaged in trade on behalf of firms doing business outside the state); Asher v Texas, 128 US 129 (1888) (invalidating a state privilege tax as applied to agents representing out-of-state firms); Corson $v$ Maryland, 120 US 502,505-06 (1887) (invalidating a state licensing requirement as applied to an agent of a New York firm soliciting sales in Maryland).

93 Robbins v Shelby County Taxing District, 120 US 489, 498 (1887) (invalidating a state privilege tax as applied to dealers of paper products representing foreign-state firms).

94 Id.

95 Id at 498-99.

96 See James W. Ely, Jr., The Chief Justiceship of Melville W. Fuller, 1888-1910 141 (South Carolina 1995) (arguing that the objective of the Court was to establish a national market for goods); Owen M. Fiss, 8 History of the Supreme Court of the United States: Troubled Beginnings of the Modern State, 1888-1910 66, 259, 266, 270, 274, 278-79, 291 (Macmillan 1993); McCurdy, The Knight Sugar Decision at 309-14 (cited in note 5); Charles W. McCurdy, American Law and the Marketing Structure of the Large Corporation, 1875-1890,38 J Econ Hist 631 (1978) (arguing that the Court's dormant Commerce Clause jurisprudence enabled the growth of American industry); Bickel, Unpublished Opinions at 100 (cited in note 51); James Willard Hurst, Law and the Conditions of Freedom in the Nineteenth-Century United States 44-51 (Wisconsin 1956) (discussing the effect of court action in the absence of preemptive federal legislation). 
and the unrestricted movement of wheat, ore and coal in this country cannot be overestimated."

Commentators observed that this refashioning of dormant Commerce Clause jurisprudence proceeded upon the theory that Congress's power to regulate interstate commerce was exclusive. ${ }^{98}$ But use-

97 Charles Warren, 2 The Supreme Court in United States History 627 (Little, Brown 1937). Warren referred to the State Freight Tax Case, 82 US (15 Wall) at 232.

98 See Kallenbach, Federal Cooperation at 8-9, 18, 27, 31, 40-41, 44-45 (cited in note 73) (explaining the negative implications of the Commerce Clause); Edward Corwin, Commerce Power at 152 (cited in note 5) ("[T] he Court had firmly established the doctrine that Congress's power under the commerce clause is as to most important matters an exclusive power. The consequence of this doctrine is that any State law which, in the judgment of the Court, affects interstate commerce to such an extent as to 'regulate' it, is ipso facto void. This doctrine has been highly beneficial in permitting business interests to spread over the country without much regard to State lines."); John B. Sholley, The Negative Implications of the Commerce Clause, 3 U Chi L Rev 556, 583 (1936) (analyzing the Commerce Clause amidst congressional silence); Gavit, The Commerce Clause at 4-9, 15-20, 27, 127, 160 (cited in note 72); Cooke, The Commerce Clause at iv, 110-20, 137 (cited in note 72) (describing Commerce Clause jurisprudence in the absence of congressional action); James S. Rogers, The Exclusiveness of the Power of Congress Over Interstate and Foreign Commerce, 44 Am L Reg (new series) 539, 593 (1905); David Walter Brown, The Exclusive Power of Congress to Regulate Interstate and Foreign Commerce, 4 Colum L Rev 490, 491, 497-99 (1904) (claiming that the Commerce Clause prevented states from asserting wholly local interests to justify regulating interstate commerce); A.H. Wintersteen, The Commerce Clause and the State, 28 Am L Reg (new series) 733, 737-42 (1889); Louis M. Greeley, What is the Test of a Regulation of Foreign or Interstate Commerce?, 1 Harv L Rev 159, 174-75, 183 (1887). Kallenbach maintained that "under the influence of nationally minded judges" the exclusive power theory's "acceptance and application became a matter of such common occurrence as to make it a truism of American constitutional law." Kallenbach, Federal Cooperation at 40.

For judicial expressions of the exclusive power view, see, for example, Helson and Randolph $v$ Kentucky, 279 US 245, 248 (1929) ("Regulation of interstate and foreign commerce is a matter committed exclusively to the control of Congress."); Pennsylvania v West Virginia, 262 US 553, 596 (1923) ("[T] he power to regulate interstate commerce is expressly committed to Congress and therefore impliedly forbidden to the States."); Heisler v Thomas Colliery Co, 260 US 245, 259 (1922) ("The action of the State as a regulation of interstate commerce does not depend upon the degree of interference; it is illegal in any degree."); Texas Co, 258 US at 475 (Excessive inspection fees constitute "a burden upon the commerce amounting to a regulation of it, and hence [are] invalid because inconsistent with the exclusive authority of Congress over that subject."); Bethlehem Motors Corp v Flynt, 256 US 421, 427 (1921) (Imposition of tax is "practically the usurpation of the power of Congress over interstate commerce, and therefore illegal."); Pure Oil Co v Minnesota, 248 US 158, 162 (1918) (An excessive inspection fee "will be declared void because constituting, in its operation, an obstruction to and burden upon that commerce among the States the exclusive regulation of which is committed to Congress by the Constitution."); International Paper Co v Massachusetts, 246 US 135, 141 (1918) ("Under the commerce clause exclusive power to regulate interstate commerce rests in Congress, and a state statute which either directly or by its necessary operation burdens such commerce is invalid, regardless of the purpose with which it was enacted."); Sligh v Kirkwood, 237 US 52, 58 (1915) ("That Congress has the exclusive power to regulate interstate commerce is beyond question."); Railroad Commission of Ohio $v$ Worthington, 225 US 101, 107 (1912) ("It is not necessary to review the cases in this court which have settled beyond peradventure that the National Government has exclusive authority to regulate interstate commerce under the Constitution of the United States."); Southern Railway Co v King, 217 US 524, 531 (1910) ("[T]he right to regulate interstate commerce is, by virtue of the Federal Constitution, exclusively vested in the Congress of the United States."); Adams Express Co, 206 US at 135 (Transaction was "one of interstate commerce, and within the exclusive 
ful as the exclusive power theory may have been for purposes of razing state trade barriers, it, like the government's argument in Schechter, proved too much." As Bernard Gavit put it, "The immediately exclusive theory took in too much territory." If that theory

were followed to its logical conclusion the result [would have been] nothing short of disastrous. ... If the exclusiveness of Federal control were given its apparently logical application all but a small part of the conduct and interests of persons engaged in interstate and foreign commerce [would have been] outside of any law. It would have been incumbent upon Congress to have legislated immediately and in detail on the subject, - an impossible task.

jurisdiction of Congress."); Asbell v Kansas, 209 US 251, 254 (1908) ("The governmental power over the commerce which is interstate is vested exclusively in the Congress by the commerce clause of the Constitution, and therefore is withdrawn from the States."); Iroquois Transportation Co v DeLaney Forge Co ("The Winnebago"), 205 US 354, 363 (1907) ("[T] he Constitution gives exclusive jurisdiction [over interstate commerce] to Congress."); E.U. McLean \& Co v Denver \& Rio Grande Railroad Co, 203 US 38, 49-50 (1906) ("It has been too frequently decided by this court to require the restatement of the decisions, that the exclusive power to regulate interstate commerce is vested by the Constitution in Congress."); Harmon v Chicago, 147 US 396, 407 (1893) (Ordinance is "plainly and palpably in conflict with the exclusive power of Congress to regulate commerce, interstate and foreign."); Crutcher v Kentucky, 141 US 47,59-60 (1891) ("[I]t does not follow that everything which the legislature may deem essential for the good order of society and the well being of its citizens can be set up against the exclusive power of Congress to regulate the operations of foreign and interstate commerce."); Lyng $v$ Michigan, 135 US 161,166 (1890) (" $[N]$ o state has the right to lay a tax on interstate commerce in any form, whether by way of duties laid on the transportation of the subjects of that commerce, or on the receipts derived from that transportation, or on the occupation or business of carrying it on, for the reason that such taxation is a burden on that commerce, and amounts to a regulation of it, which belongs solely to Congress."); Walling $v$ Michigan, 116 US 446, 455 (1886) ("We have so often held that the power given to Congress to regulate commerce with foreign nations, among the several States and with the Indian Tribes, is exclusive in all matters which require, or only admit of, general and uniform rules."); Brown v Houston, 114 US 622, 630-31 (1885) (The power of Congress over commerce among the States "is certainly so far exclusive that no State has power to make any law or regulation which will affect the free and unrestrained intercourse and trade between the States. ... All laws and regulations are restrictive of natural freedom to some extent, and where no regulation is imposed by the government which has the exclusive power to regulate, it is an indication of its will that the matter shall be left free."); County of Mobile $v$ Kimball,102 US 691,697 (1880) ("[C]ommerce with foreign countries or between the States which consists in the transportation, purchase, sale, and exchange of commodities ... can of necessity be only one system or plan of regulations, and that Congress alone can prescribe.").

99 See Greeley, 1 Harv L Rev at 181 (cited in note 98).

100 Gavit, The Commerce Clause at 16 (cited in note 72).

101 Id at 8-9. Alexander Bickel agreed that "the doctrine could not be maintained" so "sweepingly and rigidly." He noted:

It was never intended, by encouraging the free flow of commerce, to impair the existence of the states as viable units of government. Yet that would have been the result of the successful operation of the Commerce Clause, if in promoting the rise of a national economy it had been permitted to withdraw more and more and finally nearly all wealth-producing activity from the regulatory and taxing jurisdiction of the several states. The problem has been to balance the needs of a state as against those of the nation, and not to force the sacrifice of 
Such a conclusion, wrote Frederick Cooke, would have been "intolerable." ${ }^{\text {102 }}$ It would have opened a regulatory vacuum beyond Edward Corwin's worst nightmares.

The doctrinal categories through which the Justices avoided these undesirable consequences of the exclusive power theory are familiar to students of the Court's affirmative Commerce Clause jurisprudence. The Court consistently maintained that regulations touching a "national"

what is vital to the one for the sake of what is trivial to the other.

Bickel, Unpublished Opinions at 100 (cited in note 51).

102 Cooke, The Commerce Clause at 120 (cited in note 72). David Walter Brown remarked that if "the States were deprived of the right to legisiate upon all subjects connected with [interstate] commerce, local self government and the autonomy of the States would become illusory." Brown, 4 Colum L Rev at 491 (cited in note 98). George G. Reynolds concurred: "To declare that all state legislation affecting interstate commerce was prohibited by the commerce clause was manifestly impossible; the indirect effects of legislation required by local needs are so widespread and so easily reach interstate commerce, that such an interpretation would have destroyed the governments of all the states." George G. Reynolds, The Distribution of Power to Regulate Interstate Carriers Between the Nation and the States 77 (Columbia 1928).

103 See Edward S. Corwin, The Passing of Dual Federalism, in R.G. McCloskey, ed, Essays in Constitutional Law 185, 208 (Knopf 1957) (criticizing Hammer v Dagenhart, 247 US 251 (1918), for creating a "realm of no-power, a 'twilight zone,' a 'no-man's land' in which corporate enterprise was free to roam largely unchecked").

104 See, for example, Caldwell, 187 US at 625 ("The Constitution of the United States, having given to Congress the power to regulate commerce ... among the several States, that power is necessarily exclusive whenever the subjects of it are national in their character, or admit only of one uniform system or plan of regulation."); Western Union Telegraph Co v James, 162 US 650, 655 (1896) ("The matters upon which the silence of Congress is equivalent to affirmative legislation are national in their character."); Covington \& Cincinnati Bridge Co, 154 US at 212 ("[W] herever such laws, instead of being of a local nature and not affecting interstate commerce but incidentally, are national in their character, the non-action of Congress indicates its will that such commerce shall be free and untrammelled, and the case falls within the [category] of those laws wherein the jurisdiction of Congress is exclusive."); In re Rahrer, 140 US 545, 555 (1891) ("The power of Congress to regulate commerce among the several states, when the subjects of that power are national in nature, is also exclusive."); Bowman, 125 US at 507-08 ("[W] subject is national in its character, and admits and requires uniformity of regulation, affecting alike all the States, such as transportation between the States, including the importation of goods from one State into another, Congress can alone act upon it and provide the needed regulations."); Robbins, 120 US at 492 ("[T]he Constitution of the United States having given to Congress the power to regulate commerce ... among the several states, that power is necessarily exclusive whenever the subjects of it are national in their character."); Brown, 114 US at 630 ("[T]he power of Congress is exclusive wherever the matter is national in its character or admits of one uniform system or plan of regulation."); Gloucester Ferry Co y Pennsylvania, 114 US 196, 204 (1885) ("[W]hen [the subjects] are national in their character, and require uniformity of regulation affecting alike all the states, the power of Congress is exclusive."); Tiernan, 102 US at 126 ("[W] ture as to admit of uniformity of regulation, the power is exclusive of State authority."); Welton, 91 US at 280 ("[W]here the subject to which the power applies is national in its character, or of such a nature as to admit of uniformity of regulation, the power is exclusive of all State authority."); State Freight Tax Case, 82 US (15 Wall) at 279-80 ("[W]henever the subjects over which a power to regulate commerce is asserted are in their nature national, or admit of one uniform system or plan of regulation, they may justly be said to be of such a nature as to require exclusive legislation by Congress."); Hinson, 75 US at 152 ("[T]here is a class of legislation of a general na- 
unconstitutional. ${ }^{105}$ But where "local" matters were concerned, any valid exercise of the police power ${ }^{106}$ or the power to tax that affected

ture, affecting the commercial interests of all the States, which, from its essential character, is National, and which must, so far as it affects these interests belong exclusively to the Federal government.").

105 See, for example, Helson and Randolf, 279 US at 249 ("[A] state law which directly burdens [interstate] commerce by taxation or otherwise, constitutes a regulation beyond the power of the state under the Constitution."); Kansas Natural Gas Co, 265 US at 307 ("In the absence of congressional legislation, a State may constitutionally impose taxes, enact inspection laws, quarantine laws and, generally, laws of internal police, although they may have an incidental effect on interstate commerce. But the commerce clause of the Constitution, of its own force, restrains the States from imposing direct burdens upon interstate commerce."); Standard Oil Co, 249 US at 396-97 (Excessive inspection fee "imposes a direct burden upon" interstate commerce.); Looney y Crane Co, 245 US 178, 187 (1917) (striking down state taxes imposing "direct burdens on interstate commerce"); Seaboard Air Line Railway Co,244 US at 315 ("[T] he power of the State cannot be exercised to directly burden interstate commerce."); Kansas City Railway v Botkin, 240 US 227, 231 (1916) (State may not impose a tax which "has such a direct relation to interstate commerce as to be an exercise of a power prohibited by the commerce clause."); Rossi, 238 US at 66 (State legislation which "directly interferes with" interstate transportation of liquor violates commerce clause.); Kansas City Southern Railway Co, 233 US at 79 ("[A] direct interference with commerce among the States could not be justified" "by simply invoking the convenient apologetics of the police power."); Crenshaw, 227 US at 395 (State licensing law "imposes a direct burden upon interstate commerce, exclusively within Federal control, and therefore beyond the power of the State to regulate."); Worthington, 225 US at 111 (invalidating state statute that "attempted to directly regulate and control interstate commerce"); Southern Railway Co v King, 217 US 524, 531 (1910) ("The States cannot pass any law directly regulating [interstate] commerce."); West v Kansas Natural Gas Co, 221 US 229, 262 (1911) ("[N]o State can by action or inaction prevent, unreasonably burden, discriminate against, or directly regulate interstate commerce or the right to carry it on."); Wabash, St. Louis \& Pacific Railway Co, 118 US at 589 (Bradley dissenting) ("[D]irect regulations and burdens upon [interstate commerce] come fairly within the exclusive prerogatives of Congress."); Interstate Sand and Car Transfer Co, 192 US at 469-70 (striking down state licensing requirement imposing "a direct burden upon interstate commerce"); Brennan, 153 US at 304 ("[W] the State can go, it cannot go so far as to uphold any regulations directly affecting interstate commerce."); Bowman, 125 US at 498 (invalidating “a regulation directly affecting interstate commerce in an essential and vital point").

106 See, for example, Sligh, 237 US at 58,61 (upholding state statute making it a crime to deliver citrus fruits unfit for consumption, noting that "the competency of the State to provide local measures in the interest of the safety and welfare of the people is not doubted, although such regulations incidentally and indirectly involve interstate commerce .... [T] he mere fact that interstate commerce is indirectly affected will not prevent the State from exercising its police power"); Hendrick v Maryland, 235 US 610,622 (1915) (upholding state automobile registration requirement as "but an exercise of the police power uniformly recognized as belonging to the States and essential to the preservation of the health, safety and comfort of their citizens," which did "not constitute a direct and material burden on interstate commerce"); King, 217 US at 532 (" $[T]$ he rights of the States to pass laws not having the effect to regulate or directly interfere with the operations of interstate commerce, passed in the exercise of the police power of the State in the interest of the public health and safety, have been maintained by the decisions of this court."). See also H.J. Davenport, State Taxation of Interstate Commerce, I, 26 Pol Sci Q 643 (1911) (describing the state power to tax within Commerce Clause limits); Charles C. Bonney, The Relation of the Police Power of the States to the Commerce Power of the Nation, $25 \mathrm{Am} \mathrm{L}$ Rev 159 (1891) (delineating the scope of the police power). 
interstate commerce only "incidentally" 107 or "indirectly" constitute impermissible encroachment upon the national domain." As Justice Hughes put it in the Minnesota Rate Cases, ${ }^{110}$ which formed the basis for his opinion in Shreveport" the following year, "If a state enactment imposes a direct burden upon interstate commerce, it must fall regardless of Federal legislation;" "112 but "it is competent for a State

107 Kallenbach, Federal Cooperation at 8 (cited in note 73) (asserting that states have a power to regulate commerce in its strictly local aspects); Gavit, The Commerce Clause at 7 (cited in note 72); Cooke, The Commerce Clause at 119-20 (cited in note 72) (claiming that the states cannot be deprived of all power to regulate when commerce is at all affected); Paul Fuller, Is There a Federal Police Power?, 4 Colum L Rev 563, 587 (1904) (arguing that incidental interference with state commerce is permitted); Lewis, The Federal Commerce Power at 38-39 (cited in note 72); Charles A. Culberson, The Supreme Court and Interstate Commerce, 24 Am L Rev 25, 38 (1890) ("It is not thought that the power does or was ever intended to take from the States their inherent and reserved right to legislate upon all subjects of an internal or domestic nature, even though in so doing foreign and interstate commerce may be indirectly or incidentally involved.").

108 See, for example, Atlantic Lumber Co v Commissioner, 298 US 553, 557 (1936) (upholding tax where "the effect upon interstate commerce, so far as there is any, is remote and incidental"); Hartford Accident \& Indemnity Co v McLaughlin, 298 US 155, 158 (1936) (upholding merchant licensing law having only an "indirect and incidental" effect upon interstate commerce); Pacific Telephone \& Telegraph Co, 297 US at 419 (upholding tax "laid upon intrastate commerce only and [ ] not shown to be a direct burden upon interstate commerce"); Hump Hairpin Mantfacturing Co v Emmerson, 258 US 290, 294 (1922) (upholding "a state excise tax which affects [interstate] commerce, not directly, but only incidentally and remotely"); Denver \& Rio Grande Railroad Co v City of Denver, 250 US 241, 246 (1919) (upholding ordinance affecting interstate commerce "only incidentally and indirectly"); United States Glue Co v Town of Oak Creek, 247 US 321, 326 (1918) ("It is settled that a State may not directly burden interstate commerce, either by taxation or otherwise. But a tax that only indirectly affects the profits or returns from such commerce is not within the rule."); Silz v Hesterberg, 211 US 31, 40-41 (1908) ("That a state may not pass laws directly regulating foreign or interstate commerce has frequently been held in the decisions of this court. But ... laws passed by the States in the exertion of their police power, not in conflict with laws of Congress upon the same subject, and indirectly or remotely affecting interstate commerce, are nevertheless valid laws."); Allen v Pullman's Palace Car Co, 191 US 171, 180-81 (1903) (While the Court's dormant commerce clause cases "show a zealous care to preserve the exclusive right of Congress to regulate interstate traffic, the corresponding right of the State to tax and control the internal business of the State, although thereby foreign or interstate commerce may be indirectly affected, has been recognized with equal clearness."); Ficklen $v$ Shelby County Taxing District, 145 US 1,24 (1892) (upholding local occupation tax that affected interstate commerce only "incidentally, and so remotely as not to amount to a regulation of such commerce"); Sherlock v Alling, 93 US 99, 103 (1876) ("In conferring upon Congress the regulation of commerce, it was never intended to cut the States off from legislating on all subjects relating to the health, life, and safety of their citizens, though the legislation might indirectly affect the commerce of the country. Legislation, in a great variety of ways, may affect commerce and persons engaged in it without constituting a regulation of it, within the meaning of the Constitution.").

109 This is noted in Stone, et al, Constitutional Law at 290-92 (cited in note 1). The creation of the distinction between direct and indirect effects on commerce has been credited to Justice Field's opinion in Sherlock, 93 US at 103. See John B. Sholley, The Negative Implications of the Commerce Clause, $3 \mathrm{U}$ Chi L Rev at 582 (cited in note 98).

110 Simpson v Shepard ("Minnesota Rate Cases"), 230 US 352 (1913).

111234 US at 350-51.

112 The Minnesota Rate Cases, 230 US at 396 (emphasis added). See also id at 399-400 (detailing the reasoning behind the negative implications of the Commerce Clause). 
to govern its internal commerce, to provide local improvements, to create and regulate local facilities, to adopt protective measures of a reasonable character in the interest of the health, safety, morals and welfare of its people, although interstate commerce may incidentally or indirectly be involved." ${ }^{113}$ Hughes explained this in terms he would echo in his Schechter opinion two decades later:

In the intimacy of commercial relations, much that is done in the superintendence of local matters may have an indirect bearing upon interstate commerce. The development of local resources and the extension of local facilities may have a very important effect upon communities less favored and to an appreciable degree alter the course of trade. The freedom of local trade may stimulate interstate commerce, while restrictive measures within the police power of the State enacted exclusively with respect to internal business, as distinguished from interstate traffic, may in their reflex or indirect influence diminish the latter and reduce the volume of articles transported into or out of the State. ${ }^{114}$

As Hughes observed, however, the Court had consistently rejected the contention that such indirect effects upon commerce rendered such state regulations constitutionally infirm. ${ }^{115}$ Justice Holmes put it this way in Diamond Glue Co v United States Glue Co: ${ }^{116}$

In modern societies every part is related so organically to every other, that what affects any portion must be felt more or less by all the rest. Therefore, unless everything is to be forbidden and legislation is to come to a stop, it is not enough to show that, in the working of a statute, there is some tendency, logically discernible, to interfere with commerce.... Practical lines have to be drawn."

The "practical lines" to be drawn in order to prevent the dormant Commerce Clause from prohibiting all state regulation were the dis-

113 Id at 402 . Following the Minnesota Rate Cases in upholding local rate regulation affecting commerce only "incidentally" were Louisville \& Nashville Railroad Co v Garrett, 231 US 298 (1913); Allen v St Louis, Iron Mountain \& Southern Railway Co, 230 US 553 (1913); Southern Pacific Co v Campbell, 230 US 537 (1913); Oregon Railroad \& Navigation Co v Campbell, 230 US 525 (1913); Chesapeake \& Ohio Railway Co v Conley, 230 US 513 (1913); Missouri Rate Cases, 230 US 474.

114 Minnesota Rate Cases, 230 US at 410-11.

115 Id.

116187 US 611 (1903).

117 Id at 616. For another instance of Holmes's concern with the preservation of state regulatory and taxing prerogatives through the drawing of "practical lines" in dormant Commerce Clause cases, see Superior Oil Co v Mississippi, 280 US 390,395 (1929) (upholding imposition of tax on distributors of gasoline, noting that it "is important to prevent [the commerce] clause being used to deprive the States of their lifeblood by a strained interpretation of facts"). 
tinctions between the "local" and the "national," and between "direct" and "indirect" effects."

The Justices employed this vocabulary rather indiscriminately across a broad range of cases, causing no end of confusion and consternation among contemporary commentators. ${ }^{119}$ For present purposes, it is important only that we distinguish between two types. The first class of cases, descending from Cooley $v$ Board of Wardens of the Port of Philadelphia, ${ }^{120}$ recognized subjects over which Congress's jurisdiction was paramount but not exclusive. With respect to such matters, it was held, "[T]he States may legislate in the absence of congressional regulations." In such instances, wrote Justice Curtis, "[T] he nature of the subject" was "such, that until Congress should find it necessary to exert its power, it should be left to the legislation of the States." ${ }^{12}$ Such matters were "local and not national," and were "likely to be the best provided for, not by one system, or plan of regulations, but by as many as the legislative discretion of the several States should deem applicable" to local conditions. ${ }^{123}$ As Justice Field later put it, "[W] here the subjects on which the power may be exercised are local in their nature or operation, or constitute mere aids to commerce, the authority of the State may be exerted for their regulation and management until Congress interferes and supersedes it." ${ }^{124}$ As F.D.G. Ribble summarized the rule in 1937, "It thus appears that a state statute, dealing with subjects of interstate commerce which demand national regulation, is per se a burden on interstate commerce

118 On Justice Brandeis's persistent fidelity to the "strangely formal" distinction between direct and indirect effects in dormant Commerce Clause cases, see Bickel, Unpublished Opinions at 115-18, 128, 132-33, 155, 195-96 (cited in note 51). See, for example, Cudahy Packing Co v Hinkle, 278 US 460, 470 (1929) (Brandeis dissenting) (claiming that a corporate tax only indirectly affected commerce); Ozark Pipe Line Corp v Monier, 266 US 555, 569-70 (1925) (Brandeis dissenting) (arguing that a tax on a corporation engaged in interstate commerce only indirectly affected such commerce); Texas Transport \& Terminal Co v City of New Orleans, 264 US 150, 155 (1924) (Brandeis dissenting) (asserting that a tax on a shipping business only indirectly affected interstate commerce).

119 See, for example, Ribble, State and National Power at 202-06, 216-23, 230, 234-35 (cited in note 72) (claiming that the precise meaning of these terms was often unclear); Gavit, The Commerce Clause at ch 1 (cited in note 72 ).

12053 US (12 How) 299 (1851).

121 Id at 319.

122 Id.

123 Id.

124 Escanaba Co v Chicago, 107 US 678, 687 (1882) (holding that states have plenary control over navigable rivers until Congress acts). See also Walter C. Noyes, Development of the Commerce Clause of the Constitution, 16 Yale L J 253, 257-58 (1907) ("It is only in the case of local matters-in matters which are rather auxiliary to commerce than a part of it-that the states have power to act in the absence of action by Congress."); Prentice and Egan, The Commerce Clause at 28 (cited in note 72) ("[I]n matters of local nature, such as are auxiliary to commerce rather than a part of it, the inaction of Congress is to be taken as an indication that for the time being, and until it sees fit to act, they may be regulated by State authority."). 
or, otherwise expressed, directly affects that commerce. Similarly, state statutes dealing with those subjects which admit of local regulation affect interstate commerce indirectly."

Although the Court applied the Cooley rule in a variety of cases, some examples may provide a sense of its limited scope. ${ }^{126}$ Nondiscriminatory labeling and inspection statutes imposing only reasonable fees were sustained, notwithstanding their "indirect and incidental" effect on interstate commerce. ${ }^{127}$ State quarantine statutes also passed constitutional muster, even though they "may incidentally or indirectly affect" interstate commerce. ${ }^{128}$ Grain elevators were only "inci-

125 Ribble, State and National Power at 221 (cited in note 72). In 1922, C.K. Burdick observed,

[I]n a large number of cases, and particularly in those of more recent date, the Supreme Court has recognized that the States in the exercises of their police power for the protection of their citizens, may incidentally, and sometimes quite directly, affect interstate commerce, and has declared that this is not an unconstitutional invasion of the field of congressional legislation, as long as the state action constitutes a bona fide exercise of the police power, and does not unduly burden interstate commerce, and is not in conflict with any existing federal legislation. It would seem that this principle would include all those cases which have been held to fall within the doctrine framed in the Port Wardens case, and that it states the basis of state action more satisfactorily. It is not surprising, therefore, that we hear less and less of the States' concurrent power over interstate commerce, and more of the validity of state police regulations which incidentally affect such commerce.

Burdick, The Law of the American Constitution at 244-45 (cited in note 76).

126 Justice Stone offered a catalog in South Carolina Highway Department v Barnwell Brothers, Inc, 303 US 177 (1938). He listed state regulation of "its own highways, canals and railroads" "intrastate carriers," id at 187 , "those which sanction obstructions in navigable rivers, approve the erection of bridges over navigable streams, require payment of fees as an incident to use of harbors, control the location of docks, impose wharfage charges, establish inspection and quarantine laws, and regulate the taking or exportation of domestic game." Id at $188 \mathrm{n} 5$ (citations omitted). See also, for example, Westel W. Willoughby, Principles of the Constitutional Law of the United States 1000-01 (New York 2d ed 1929); Judson, The Law of Interstate Commerce at 40-41 (cited in note 72); Frank J. Goodnow, The Power of Congress to Regulate Commerce, 25 Pol Sci Q 220, 223 (1910) (State may, "in the absence of action by Congress," regulate such "local matters" as "pilotage, quarantine, port regulations and wharfage."); Prentice and Egan, The Commerce Clause at 27 (cited in note 72) ("[T]he States may establish port regulations, regulations of pilotage, may improve their harbors and rivers, erect bridges and dams.").

127 Savage $v$ Jones, 225 US 501, 528 (1912) (inspection charge for stock food). See also Corn Products Refining Co v Eddy, 249 US 427, 432 (1919) (upholding a Kansas requirement that corn syrup containers include a label displaying ingredients despite its "incidental interference" with interstate commerce); Pure Oil Co, 248 US 158 (illuminating oils and gasoline); Standard Stock Food Co v Wright, 225 US 540 (1912) (stock food); Lindsay and Phelps Co v Mullen, 176 US 126 (1900) (lumber); Patapsco Guano Co v North Carolina Board of Agriculture, 171 US 345 (1898) (fertilizer).

128 Missouri, Kansas and Texas Railway Co v Haber, 169 US 613,627 (1898) (upholding cattle quarantine statute). See, for example, Clason v Indiana, 306 US 439, 443 (1939) (upholding statute requiring license to transport large dead animals not slaughtered for human consumption on the state highways as an "appropriate sanitary measure whose effect upon interstate commerce, if any, is merely incidental"); Mintz v Baldwin, 289 US 346, 350 (1933) (upholding cattle inspection law); Asbell, 209 US at 255-56 (upholding state cattle inspection statute as a valid exercise of the police power); Reid v Colorado, 187 US 137, 148-49 (1902) (upholding cattle quarantine statute); Compagnie Francaise de Navigation a Vapeur v Louisiana State Board of Health, 
dentally" connected with interstate commerce, and regulation of their rates was "a thing of domestic concern" operating on interstate commerce only "indirectly." With respect to this class of cases, the permissibility of state regulation did not preclude federal action. In each instance the opinion indicated that regulation of the matter in question was within congressional competence.

It was sometimes remarked of the statutes in this first class of cases that, while they might "affect" interstate commerce, they were not "regulations" of it "in the constitutional sense." In the second class of cases, however, the Court did not regard the statutes in question as regulating interstate commerce at all. They might operate before interstate commerce had begun, or after it had ceased, but they did not regulate subject matter entrusted to Congress under the Commerce Clause. As in the first class of cases, the opinions in the

186 US 380,390-91 (1902) (permitting state to restrict travel through quarantined areas); Smith $v$ St. Louis and Southwestern Railway Co, 181 US 248, 257-58 (1901) (upholding quarantine statute); Rasmussen v Idaho, 181 US 198, 201-02 (1901) (upholding statute forbidding shipment of diseased cattle into the state); Morgan's Steamship Co v Louisiana Board of Health, 118 US 455 (1886) (upholding quarantine laws). Overly broad quarantines against cattle were by contrast invalid. See Railroad Co v Husen, 95 US 465, 472 (1878) (prohibiting importation in response to a minor threat of disease; a state "may not, under the cover of exerting its police powers, substantially prohibit or burden either foreign or inter-state commerce," "beyond what is absolutely necessary for its self-protection").

129 Munn v Illinois, 94 US 113, 135 (1877) (permitting state regulation of grain elevator rates). See also, for example, Merrick $v$ N.W. Halsey \& Co, 242 US 568, 585-86 (1917) (State blue sky laws purporting to regulate only those who dealt in securities "within" the state sustained on the ground that they affected interstate commerce only "incidentally," imposing only an "indirect" burden.); Caldwell v Sioux Falls Stock Yards Co, 242 US 559 (1917) (upholding state blue sky laws); Hall $v$ Geiger-Jones Co, 242 US 539, 557-58 (1917) (holding that a state may require securities dealers to obtain licenses for sales in the state); Erie Railroad Co $v$ Williams, 233 US 685, 704 (1914) (New York statute requiring common carriers to pay their employees in cash on a semi-monthly basis imposed only an "indirect burden" on interstate commerce and was accordingly valid.).

130 Galveston, Harrisburg and San Antonio Railway Co v Texas, 210 US 217, 225 (1908) ("[N]ot every law that affects commerce among the States is a regulation of it in a constitutional sense."). See also The Winnebago, 205 US at 362 ("The State may pass laws enforcing the rights of its citizens which affect interstate commerce but fall short of regulating such commerce in the sense in which the Constitution gives exclusive jurisdiction to Congress.");New York, New Haven and Hartford Railway Co v New York, 165 US 628, 632 (1897) (State prohibition on internal furnaces on passenger cars was not "within the meaning of the Constitution a regulation of commerce, although it controls, in some degree, the conduct of those engaged in such commerce."); Railroad Co, 95 US at 472 ("Many acts of a State may, indeed, affect commerce, without amounting to a regulation of it, in the constitutional sense of the term."); Reading Railroad Co v Pennsylvania ("Railway Gross Receipts Tax Case"), 82 US (15 Wall) 284, 293 (1872) ("[I]t is not everything that affects commerce that amounts to a regulation of it, within the meaning of the Constitution."). See Gavit, The Commerce Clause at 21 (cited in note 72); Blewett H. Lee, Limitations Imposed by the Federal Constitution on the Right of the States to Enact Quarantine Laws I, 2 Harv L Rev 267, 279-80 (1889); John Norton Pomeroy, The Power of Congress to Regulate Inter-State Commerce, 4 So L Rev 357, 359-60, 390-93 (1879). See also Limitations Imposed by the Federal Constitution on the Right of the States to Enact Quarantine Laws II, 2 Harv L Rev 293, 314-15 (1889) (detailing legislation that fell short of "regulating," yet still "affected," commerce). 
second class might characterize such statutes as "affecting" interstate commerce "incidentally," "indirectly," or "remotely." But here these terms had a different significance. There was no suggestion in these cases that these were matters over which Congress might assert its regulatory authority. Such matters were "purely" or "essentially" "local," subject solely to state and local regulation, beyond the reach of the commerce power.

Chief among the areas in which these distinctions were felt were licensing and taxation. The Court upheld a series of nondiscriminatory licensing, privilege, occupation, and sales taxes that applied to local sales of interstate goods only after they had come to rest in the destination state. ${ }^{131}$ The Court similarly sustained nondiscriminatory state and local taxation of property that had travelled in interstate com-

131 See, for example, Monamotor Oil Co v Johnson, 292 US 86, 95 (1934) (upholding tax on motor vehicle fuel that had "come to rest" in the taxing state); Magnano Co v Hamilton, 292 US 40, 43 (1934) (upholding tax on oleomargarine "confined to sales within the state, and [having] no application to sales of oleomargarine to be either imported or exported in interstate commerce"); East Ohio Gas Co v Tax Commission of Ohio, 283 US 465, 471 (1931) (upholding privilege tax on delivery of out-of-state natural gas to local consumers through local distribution system, "a business of purely local concern exclusively within the jurisdiction of the State"); Gulf Fisheries Co v MacInerney, 276 US 124, 126 (1928) (upholding a license tax on wholesale dealers in fish, where the "fish have lost their alleged distinctive character as imports and have become, through processing, handling and sale, a part of the mass of property subject to taxation by the State"); Sonneborn Brothers v Cureton, 262 US 506, 508 (1923) (upholding a state occupation tax levied on wholesale dealers in oil that "had come to a state of rest" in the taxing state); Bowman, 256 US at 648-49 (upholding an excise tax on local sales of gasoline that had "passed beyond interstate commerce"); Wagner v City of Covington, 251 US 95, 102 (1919) (upholding a nondiscriminatory license tax applied to vendors distributing their goods from out-of-state manufacturers to local merchants); Watters v Michigan, 248 US 65, 66 (1918) (upholding a licensing requirement for door to door sales of goods "that were at rest in the State before the sale"); Dalton Adding Machine Co v Virginia, 246 US 498, 499 (1918) (upholding licensing tax on company selling machines "after their transportation in interstate commerce has been concluded and they have become mingled with the general mass of property" in the taxing state); Rast $v$ Van Deman \& Lewis Co, 240 US 342,360 (1916) (upholding a state special license tax on merchants engaged in "essentially local sales"); Browning v City of Waycross, 233 US 16,22-23 (1914) (upholding occupation tax on the installation of lightning rods that had been shipped in interstate commerce as one imposed on "the carrying on of a business of a strictly local character," "the doing of a local act after interstate commerce had completely terminated," and "exclusively a local business, subject to state control"); Banker Brothers Co v Pennsylvania, 222 US 210, 213 (1911) (upholding a state tax on retail sales of automobiles that "had become at rest" in the taxing state); Kehrer v Stewart, 197 US 60, 68-69 (1905) (upholding a privilege tax on the domestic business of agents of meat packing houses even when applied to goods shipped from another state); Cook v Marshall County, 196 US 261, 274-75 (1905) (upholding local license tax on retail sales of cigarettes); Pennsylvania Railroad Co v Knight, 192 US 21, 28 (1904) (upholding privilege tax on "Iocal" cab service, "preliminary or subsequent to an interstate transportation," noting that "many things have more or less close relation to interstate commerce, which are not properly to be regarded as part of it"); Emert $v$ Missouri, 156 US 296, 321-22 (1895) (upholding nondiscriminatory license tax on peddler having the goods in his possession and selling them without any previous order); Machine Co v Gage, 100 US 676, 678-79 (1880) (upholding a nondiscriminatory state tax upon all peddlers of sewing machines). 
merce but come to rest. ${ }^{132}$ Such goods were no longer in or part of interstate commerce. At the same time, the Justices permitted state taxation of goods that were destined to be shipped across state lines but had not yet begun their interstate journeys. ${ }^{133}$ Such licensing and taxing statutes undoubtedly "affected" interstate commerce, but they did so only "incidentally" or "indirectly.", Here again, "pragmatic" reasons underwrote "formal" distinctions. As Justice Bradley explained in the

132 See, for example, Henneford $v$ Silas Mason Co, 300 US 577, 582 (1937) (upholding tax on privilege of using property after it had come to rest in the taxing state and commerce was "at an end"); Nashville, Chattanooga \& St. Louis Railway Co v Wallace, 288 US 249, 268 (1933) (upholding tax on storage and withdrawal of gasoline that had come to rest in the taxing state as imposing a burden "too indirect and remote from the function of interstate commerce itself to transgress constitutional limitations"); Gregg Dyeing Co v Query, 286 US 472, 481 (1932) (upholding a property tax levied against gasoline that had "come to rest within the State" and was there "kept for local purposes"); Texas Co, 258 US at 475 (upholding state inspection fees for gas and oil that had "passed out of interstate commerce and [ ] come to rest within the State and become a part of the general mass of property or ... the subject of domestic commerce").

133 See, for example, Edelman v Boeing Air Transport, 289 US 249, 251 (1933) (upholding tax on withdrawal from storage tanks of gasoline to be used to fuel interstate air transport); Utah Power \& Light Co v Pfost, 286 US 165, 177 (1932) (upholding a state tax on the production of electricity within the state to be transmitted outside the state of production); Eastern Air Transport v South Carolina Tax Commission, 285 US 147, 153 (1932) (upholding tax on "purely local," "intrastate sales" of gasoline to an interstate air carrier as not "imposing a direct burden upon interstate commerce"); Hope Natural Gas Co v Hall, 274 US 284, 288 (1927) (upholding state privilege tax on production of natural gas destined to be shipped in interstate commerce); Lacoste $v$ Department of Conservation of Louisiana, 263 US 545, 550-52 (1924) (upholding state severance tax on animal pelts); Oliver Iron Mining Co v Lord, 262 US 172, 178-79 (1923) (The Court upheld a state occupation tax on coal mining even though the coal extracted was to be shipped out of state to satisfy existing contracts, maintaining that " $[\mathrm{m}]$ ining is not interstate commerce, but, like manufacturing, is a local business subject to local regulation and taxation.... Its character in this regard is intrinsic, is not affected by the intended use or disposal of the product, is not controlled by contractual engagements, and persists even though the business be conducted in close connection with interstate commerce.... The ore does not enter interstate commerce until after the mining is done .... The tax may indirectly and incidentally affect such commerce ... but this is not a forbidden burden or interference."); Heisler, 260 US at 259 (holding that a state tax on coal is not an interference with interstate commerce where the coal has not yet moved from the place of preparation, although destined to be shipped out of state); American Manufacturing Co $v$ City of St. Louis, 250 US 459, 463 (1919) (upholding municipal license fee on those manufacturing goods in the city, measured by proceeds from sales); Diamond Match Co $v$ Ontonagon, 188 US 82, 96 (1903) (upholding a property tax assessed on logs stored within the state prior to their exportation); Coe v Errol, 116 US 517, 525 (1886) (upholding a tax on timber cut and stored within the state prior to shipment to another state, referring to the moment "in which they commence their final movement for transportation from the State of their origin to that of their destination" as the "point of time when they cease to be governed exclusively by the domestic law") (emphasis added).

134 See, for example, Utah Power \& Light, 286 US at 182 (upholding tax on generation of electricity even though it may "indirectly and incidentally affect" interstate commerce); Oliver Iron Mining, 262 US at 179 (upholding tax on iron mining that might affect interstate commerce "indirectly and incidentally"); American Manufacturing, 250 US at 464 (upholding municipal tax on manufacturing despite its "incidental and indirect effect" on commerce in the goods manufactured); Armour \& Co v Virginia, 246 US 1, 7 (1918) (upholding license tax on manufacture despite its "indirect and wholly negligible influence on interstate commerce"). 
leading case of Coe $v$ Errol, "It seems to us untenable to hold that a crop or a herd is exempt from taxation merely because it is, by its owner, intended for exportation. If such were the rule in many states there would be nothing but the lands and real estate to bear the taxes.", 136

The categories with which the states' powers of licensure and taxation were rescued from dormant Commerce Clause attacks had a similarly liberating effect on the exercise of the states' regulatory powers. A growing national insurance industry was subject to regulation by the several states in which they did business, because "the business of insurance" was "not commerce," and "the contract of insurance" was "not an instrumentality of commerce. The making of such a contract" was "a mere incident of commercial intercourse.","13 Insurance contracts were "local transactions, governed by the local law." "For as Justice White explained,

If the power to regulate interstate commerce applied to all the incidents to which said commerce might give rise and to all contracts which might be made in the course of its transaction, that power would embrace the entire sphere of mercantile activity in any way connected with trade between the States; and would exclude state control over many contracts purely domestic in their nature. $^{139}$

State inspection and labeling requirements imposed on a commodity produced within the regulating state but destined for interstate markets likewise passed muster, as such regulations were enforced "before [the commodity] bec[ame] an article of commerce" and thus had only a "remote" effect upon such commerce. ${ }^{\text {1*t }}$ State regulation of intrastate rail carriage similarly won the Court's approval. ${ }^{1.1}$ Local gas

135116 US 517 (1886).

136 Id at 527-28.

137 Hooper v California, 155 US 648, 655 (1894).

138 Paul $v$ Virginia, 75 US (8 Wall) 168, 183 (1869).

139 Hooper, 155 US at 655 . For additional cases in which the Court has allowed states to regulate insurance contracts, see Bothwell v Buckbee, Mears Co, 275 US 274, 276-77 (1927); Northwestern Life Insurance Co v Wisconsin, 247 US 132, 138 (1918); New York Life Insurance Co v Deer Lodge County, 231 US 495 (1913); Nutting v Massachusetts, 183 US 553 (1902); New York Life Insurance Co v Cravens, 178 US 389 (1900); Philadelphia Fire Association v New York, 119 US 110 (1886); Liverpool Insurance Co v Massachusetts, 77 US (10 Wall) 566 (1871); Ducat v Chicago, 77 US (10 Wall) 410 (1871). Concerning the power of states to regulate, license, and tax foreign corporations doing an intrastate business within the state, see generally Gerard Carl Henderson, The Position of Foreign Corporations in American Constitutional Law (Harvard 1918).

140 See, for example, Turner $v$ Maryland, 107 US 38,54,56 (1883) (allowing inspection of tobacco by states).

141 See Louisville \& Nashville Railroad v Higdon, 234 US 592,600 (1914) (upholding a state court's decision awarding damages against a railroad company that refused to provide service on 
companies selling natural gas piped in from outside the state to local consumers were engaged in "local business," and regulation of their rates related only "indirectly" to interstate commerce in natural gas. ${ }^{142}$ A state law prohibiting tobacco advertising on billboards withstood challenge because it regulated an "essentially local" activity. ${ }^{143}$ State statutes authorizing censorship of movies were likewise sustained, because interstate commerce had ended when the film had been delivered. $^{144}$

Activities of production-agriculture, mining, and manufacturing - were paradigmatically local, and their regulation by the states affected interstate commerce only indirectly. ${ }^{145} \mathrm{~A}$ Virginia statute permitting the planting of oysters in the beds of its tidewaters by state citizens survived challenge because "the planting of oysters in the soil covered by water" was "not different in principle from that of planting corn upon dry land." The case presented "no question of transportation or exchange of commodities, but only of cultivation and production. Commerce [had] nothing to do with land while producing, but only with the product after it [had] become the subject of trade." "[P]roductions [did] not spring from commerce, but commerce to some extent from them." ${ }^{145}$ Objections to Ohio statutes prohibiting the manufacture of oleomargarine colored to look like butter were "manifestly without merit. All the acts of the corporation which were complained of related to oleomargarine manufactured by it in the State of Ohio," and the regulation therefore "affected the product manufactured . . . before it had become a subject of interstate commerce."147 The Court similarly upheld a Mississippi statute prohibiting corporations engaged in the manufacture of cotton-seed oil from owning or operating cotton gins except under certain prescribed conditions:

The separation of the seed from the fiber of the cotton which is accomplished by the use of the cotton gin, is a short but important step in the manufacture of both the seed and the fiber into

\footnotetext{
a railway spur at its published rate as having only an "indirect effect" on interstate commerce); Arkadelphia Milling Co v St. Louis Southwestern Railway Co, 249 US 134,136 (1919) (permitting rate regulation of lumber transport within same state).

142 Public Utilities Commission v Landon, 249 US 236, 245-46 (1919).

143 Packer Corp v Utah, 285 US 105, 112 (1932).

144 Mutual Film Corp v Hodges, 236 US 248, 258 (1915); Mutual Film Corp v Industrial Commission of Ohio, 236 US 230, 240-41 (1915).

145 See Prentice and Egan, The Commerce Clause at 54 (cited in note 72) (explaining the distinction between manufacturing and commerce); Lewis, The Federal Power over Commerce at 4 (cited in note 72 ).

146 McCready v Virginia, 94 US 391, 396-97 (1877). See also Leonard \& Leonard $v$ Earle, 279 US 392, 397 (1929) (upholding licensure and regulation of oyster-packing establishments as a "business local in character" having "no such intimate connection with interstate commerce as to exempt it from control by the State").

147 Capital City Dairy Co v Ohio, 183 US 238, 245 (1902).
} 
useful articles of commerce, but ... manufacture is not commerce. ... And the fact, of itself, that an article when in the process of manufacture is intended for export to another State does not render it an article of interstate commerce.... [T] he manufacturing operations of the cotton gins ... precede but are not a part of interstate commerce.

The Justices accordingly rejected the company's claim that the statute imposed a "direct and substantial" burden on interstate commerce. ${ }^{1.8}$ The Court similarly sustained an Oklahoma statute prohibiting wasteful production of petroleum, finding that it applied "only to production and not to sales or transportation of crude oil or its products. Such production is essentially a mining operation and therefore is not a part of interstate commerce even though the product obtained is intended to be and in fact is immediately shipped in such commerce.,

In an era in which federal efforts to regulate intrastate activities were the exception rather than the rule, the principal function of locating such activities in the local sphere and holding that they affected interstate commerce only indirectly was not to frustrate federal regulation, but instead to insulate state and local regulatory and taxing initiatives from dormant Commerce Clause attack. ${ }^{159}$ From this vantage, we can see that formalism actually had, if anything, a proregulation valence.

Consider one final production case. An Iowa statute enacted in 1884 prohibited the manufacture of intoxicating liquors except for mechanical, medicinal, culinary, or sacramental purposes. J.S. Kidd was charged with manufacturing and selling intoxicating liquor to be taken out of the state and used as a beverage. He was convicted for violating the statute, and his distillery was abated as a nuisance. On a writ of error to the Supreme Court, Kidd contended that the statute constituted a regulation of commerce in violation of the Constitution. ${ }^{\text {ist }}$

148 Crescent Cotton Oil Co v Mississippi, 257 US 129, 136 (1921). See also Chassaniol v City of Greenwood, 291 US 584, 587 (1934) (upholding local occupation tax on cotton buyers on grounds that "[g]inning cotton, transporting it to Greenwood, and warehousing, buying and compressing it there, are each, like the growing of it, steps in preparation for the sale and shipment in interstate or foreign commerce. But each step prior to the sale and shipment is a transaction local to Mississippi, a transaction in intrastate commerce"); Federal Compress \& Warehouse Co v McLean, 291 US 17, 22 (1934) (upholding state license taxes on the operation of a cotton compress and warehouse because "the privilege taxed is exercised before interstate commerce begins, hence the burden of the tax upon the commerce is too indirect and remote to transgress constitutional limitations").

149 Champlin Refining Co v Corporation Commission of Oklahoma, 286 US 210, 235 (1932).

150 The issue, to paraphrase Edward Corwin, Commerce Power at 194 (cited in note 5), was between local regulation and no regulation.

151 Kidd v Pearson, 128 US 1 (1888). 
"The proposition that, supposing the goods were once lawfully called into existence, it would then be beyond the power of the State either to forbid or impede their exportation, may be conceded,"152 wrote Justice Lamar for a unanimous Court. For "buying and selling and the transportation incidental thereto constitute commerce; and the regulation of commerce in the constitutional sense embraces the regulation at least of such transportation."133 But Kidd had been charged not with unlawful sale or transportation of liquor, but instead with its unlawful manufacture. And, as Lamar explained, "No distinction is more popular to the common mind, or more clearly expressed in economic and political literature, than that between manufactures and commerce. Manufacture is transformation-the fashioning of raw materials into a change of form for use. The functions of commerce are different." ${ }^{\text {,15 }}$ There was of course no doubt that restrictions on manufacture would have an effect on interstate commerce in booze. But while the statute's "effects may reach beyond the State by lessening the amount of intoxicating liquors exported," it did "not follow that, because the products of a domestic manufacture may ultimately become the subjects of interstate commerce, at the pleasure of the manufacturer, the legislation of the State respecting such manufacture is an attempted exercise of the power to regulate commerce exclusively conferred upon Congress." For such a regulation did not "directly or materially affect . . . external commerce." It neither "impose[d] a direct burden upon interstate commerce" nor "interfere[d] directly with its freedom.",

All of this reads as conventional nominalist analysis. But in a sequence of strikingly pragmatic passages, Lamar explained why it was imperative to distinguish commerce from manufacture in Commerce Clause analysis:

If it be held that the term [commerce] includes the regulation of all such manufactures as are intended to be the subject of commercial transactions in the future, it is impossible to deny that it would also include all productive industries that contemplate the same thing. The result would be that Congress would be invested, to the exclusion of the States, with the power to regulate, not only manufactures, but also agriculture, horticulture, stock raising, domestic fisheries, mining - in short, every branch of human industry. For is there one of them that does not contemplate, more or less clearly, an interstate or foreign market? Does not the

\footnotetext{
152 Id at 18.

153 Id at 20.

154 Id at 20.

155 Id at 22-23.
} 
wheat grower of the Northwest, and the cotton planter of the South, plant, cultivate, and harvest his crop with an eye on the prices at Liverpool, New York, and Chicago? The power being vested in Congress and denied to the States, it would follow as an inevitable result that the duty would devolve on Congress to regulate all of these delicate, multiform and vital interestsinterests which in their nature are and must be, local in all the details of their successful management. ${ }^{156}$

"It is not necessary to enlarge on, but only to suggest the impracticability of such a scheme, when we regard the multitudinous affairs involved, and the almost infinite variety of their minute details," Lamar continued..$^{15}$ If all of these "delicate, multiform and vital" matters fell only within congressional jurisdiction, the burden on Congress would be insupportable. Congress could not simply enact "uniform legislation generally applicable throughout the United States," for "[a]ny movement toward the establishment of rules of production in this vast country, with its many different climates and opportunities, could only be at the sacrifice of the peculiar advantages of a large part of the localities in it, if not of every one of them." Instead, Congress would have to enact "a swarm of statutes only locally applicable and utterly inconsistent," which would "be about the widest possible departure from the declared object" of the Commerce Clause. ${ }^{159}$ Moreover, Congress would have to regulate not just "certain branches of industry," but "those instances in each and every branch where the producer contemplated an interstate market. These instances would be almost infinite. "16s And as if this weren't bad enough, such an interpretation would inevitably generate jurisdictional uncertainties and intergovernmental tensions. For

still there would always remain the possibility, and often it would be the case, that the producer contemplated a domestic market. In that case the supervisory power must be executed by the State; and the interminable trouble would be presented, that whether the one power or the other should exercise the authority in question would be determined, not by any general or intelligible rule, but by the secret and changeable intention of the producer in each and every act of production. A situation more paralyzing to the state governments, and more provocative of conflicts between

156 Id at 21 (emphasis added). See also Kimball, 102 US at 697 ("[L]ocal" matters "can only be properly regulated by provisions adapted to their special circumstances and localities.").

157 Kidd, 128 US at 21 (emphasis added).

158 Id at 21-22 (emphasis added).

159 Id.

160 Id (emphasis added). 
the general government and the States, and less likely to have been what the framers of the constitution intended, it would be difficult to imagine. ${ }^{161}$

Much of this language will seem familiar, if only because it is so extensively quoted in Knight. ${ }^{162}$ Indeed, Kidd $v$ Pearson was the principal authority upon which the Knight Court relied in announcing that "[c]ontracts, combinations, or conspiracies to control domestic enterprise in manufacture, agriculture, mining, production in all its forms, or to raise or lower prices. or wages, might unquestionably tend to restrain external as well as domestic trade, but the restraint would be an indirect result, however inevitable and whatever its extent." For "[s]light reflection will show that if the national power extends to all contracts and combinations in manufacture, agriculture, mining, and other productive industries, whose ultimate result may affect external commerce, comparatively little of business operations and affairs would be left for state control. ${ }^{, 163}$ If, as Lamar and his colleagues evidently maintained, the power to regulate commerce were exclusive, ${ }^{164} \mathrm{a}$ definition of commerce that included "local" productive enterprise would have deprived states of the power to regulate such enterprise, even in the absence of congressional action. ${ }^{1.5}$ This would not merely have worked a revolution in federalism-it would have been the single greatest act of deregulation in American history. For the possibility that congressional regulation sufficiently comprehensive to compensate for the displacement of state and local police powers would be forthcoming clearly appeared remote. But even in the unlikely event that Congress did undertake such a herculean task, the Justices doubted that the resulting codex could ever be sufficiently nuanced not to "sacrifice the peculiar advantages" of localities with diverse "climates and opportunities." Centralized authority could never bring

161 Id (emphasis added).

162156 US at 14-15. See text accompanying notes 67-68.

163156 US at 16.

164 As Fuller would write in Knight (after noting that the police power reserved by the states was "essentially exclusive"), "On the other hand, the power of Congress to regulate commerce among the several States is also exclusive." Id at 11.

165 The possibility that production might have been considered a "mere aid to commerce" within the meaning of Cooley, 52 US (12 How) at 230, and state and federal authority to regulate production made concurrent, does not appear to have occurred to them. As Justice Brandeis once complained of some of his colleagues to Felix Frankfurter, "What those fellows don't understand is that recognition of federal powers does not mean denial of state powers." BrandeisFrankfurter Conversations, Harvard Law School Library, quoted in Alexander M. Bickel, 9 History of the Supreme Court of the United States: The Judiciary and Responsible Government 1910 21556 (Macmillan 1984). This is precisely what they did not understand; or, put another way, they understood precisely the opposite of what Brandeis maintained. 
about "successful management" of these "delicate, multiform, and vital interests." 160

The Knight case and those that followed it were thus decided against the backdrop of a well developed dormant Commerce Clause jurisprudence-a jurisprudence whose "formalist" categories were underwritten by a set of distinctively "realistic" concerns. ${ }^{167}$ If "commerce among the several States" were to mean the same thing in affirmative and dormant Commerce Clause cases ${ }^{168}$ the categories of dormant Commerce Clause jurisprudence would have to be imported into affirmative Commerce Clause jurisprudence if they were not to be abandoned. This was recognized by a contemporary commentator, who noted that

at the passage of the Sherman Anti-Trust Act in 1890 the difference between the direct and the indirect regulation of inter-state and foreign commerce by the States had been well worked out by the Supreme Court, and it had been settled by decision upon decision ... that the indirect effect upon that commerce proceeding from the regulation of its incidents by the States was not obnoxious to the Constitution, provided the regulation was reasonable and not discriminative, however great that effect might be. It was not the degree of the effect, but the nature of the regulation which determined whether the State law was valid or invalid. After the passage of the Sherman Act the Supreme Court at once perceived the relation of this principle to the analogous question, whether only direct or also indirect and incidental restraint of that commerce was obnoxious to the Act; and it was decided upon reference to the cases which had sustained the power of the States to indirectly regulate commerce ... that only such contracts and combinations as directly, and not such as indirectly, restrained commerce were obnoxious to the Act. ${ }^{169}$

166 Compare H.P. Hood \& Sons Inc v Du Mond, 336 US 525, 545-46 (1949) (Black dissenting) (" $[\mathrm{I}] \mathrm{t}$ is inconceivable that Congress could pass uniform national legislation capable of adjustment and application to all the local phases of interstate activities that take place in the 48 states.").

167 See Ribble, State and National Power at 192-94 (cited in note 72) (noting that both the doctrine of Coe v Errol and the idea that manufacture or production is not commerce "derived from a recognition of the needs of the states for sources of revenue, and their proper claim to control of local affairs").

168 Here, perhaps, was the great "formalism," though such insistence on consistency of meaning in the construction of a single clause of the Constitution is hardly irregular.

169 D.W. Brown, The Concurrent Power of the States to Regulate Inter-State and Foreign Commerce, 5 Colum L Rev 298,306-07 (1905). See also Knight, 156 US at 16 ("[I]n Kidd v. Pearson the refusal of a State to allow articles to be manufactured within her borders even for export was held not to directly affect external commerce, and state legislation which, in a great variety of ways, affected interstate commerce and persons engaged in it, has been frequently sustained because the interference was not direct."); Fiss, 8 History of the Supreme Court at 110 (cited in 
Affirmative Commerce Clause doctrine during this period, then, was the flip side of the Court's dormant Commerce Clause jurisprudence. And that jurisprudence, as the cases make clear, was driven by frankly instrumental impulses: to secure a national market for the products of an increasingly vibrant and integrated economy, while at the same time preserving state and local prerogatives to regulate business in an era of comparative federal lassitude. ${ }^{170}$ The relative stability of this body of jurisprudence over a period of nearly four decades testifies to the degree to which the balance it struck between state and federal regulatory competence satisfied Americans of the era. ${ }^{17}$ The nationwide economic crisis of the 1930s witnessed a dramatic increase in the regulatory initiative of the federal government, and both the established federal equilibrium and the jurisprudence that prescribed and described it came to be seen as anachronistic and unsatisfactory. While these developments no doubt prompted its abandonment, they are hardly warrant for the view that "formalism" was simply the jurisprudential creed of dim-witted stooges for laissezfaire. ${ }^{\text {in }}$

\section{SOME FORMALISM ABOUT REALISM}

While "formalism" may have been conceived as a principled means of maintaining the optimal allocation of regulatory authority in an expanding yet diverse economy, "formalist" opinions certainly read differently from their "realist" counterparts. Consider, for example, Justice Holmes's opinion for a unanimous Court in Swift and Co v United States. ${ }^{133}$ Introducing the stream of commerce doctrine in upholding the application of the Sherman Act to a conspiracy to restrain trade in livestock in the Chicago stockyards, Holmes opined that

note 96$)$.

170 See Hurst, Law and the Conditions of Freedom at 50-51 (cited in note 96) ("With consistent caution the Court refused to adopt extreme doctrine as to the 'exclusive' range of national commerce power, in years when it was politically most unlikely that Congress would fill the gap left by the end of state regulations.").

171 While the categories of "formalism" had their roots in instrumental concerns, this is not to say that the cases continued regularly to manifest signs of self-conscious instrumentalism throughout the "formalist" period. It should come as no surprise that one finds more instrumental language in the germinal cases in which the categories were forged and justified than in later cases in which the categories were simply applied. As F.D.G. Ribble put it, "[F]rom results come formulations, and the formulations may control, even after their bases are lost sight of. Activities which have been called intrastate commerce will normally continue to be so called, as will other activities which bear to them some pronounced similarity." Ribble, State and National Power at 201 (cited in note 72).

172 See Felix Frankfurter, The Commerce Clause under Marshall, Taney and Waite 76 (Quadrangle 1964) (arguing that the wide discretion which formalist categories permitted was employed to achieve laissez-faire results).

173196 US 375 (1905). 
"commerce among the States is not a technical legal conception, but a practical one, drawn from the course of business." ${ }^{174}$ In Stafford $v$ Wallace ${ }^{175}$ Chief Justice Taft maintained that the Court's embrace of the stream of commerce doctrine

was the result of the natural development of interstate commerce under modern conditions. It was the inevitable recognition of the great central fact that such streams of commerce from one part of the country to another which are ever flowing are in their very essence the commerce among the States and with foreign nations which historically it was one of the chief purposes of the Constitution to bring under national protection and control. This court declined to defeat this purpose in respect of such a stream and take it out of complete national regulation by a nice and technical inquiry into the non-interstate character of some of its necessary incidents and facilities when considered alone and without reference to their association with the movement of which they were an essential but subordinate part. ${ }^{176}$

Taft concluded,

Whatever amounts to more or less constant practice, and threatens to obstruct or unduly to burden the freedom of interstate commerce is within the regulatory power of Congress under the commerce clause, and it is primarily for Congress to consider and decide the fact of the danger and meet it. This court will certainly not substitute its judgment for that of Congress in such a matter unless the relation of the subject to interstate commerce and its effect upon it are clearly non-existent. ${ }^{17}$

That language sounds distinctively "realistic." Let us therefore be "realistic" ourselves. Realism counsels us to pay attention not just to the language in the opinions, but to the way the cases come out as well. But before we can appreciate what we will discover through such an investigation, we must first peek over the hedge to see what was going on in due process jurisprudence.

As we have seen, the division of the world into national and local spheres provided the framework for the Court's federalism jurisprudence during the late nineteenth and early twentieth centuries. A similar division of the world into public and private spheres supplied the organizing principle for the Court's substantive due process jurisprudence during the same period. This principle was manifest in several

\footnotetext{
174 Id at 398.

175258 US 495 (1922).

176 Id at 518-19.

177 Id at 521.
} 
contexts; ${ }^{178}$ here I want to focus on just one. Until 1934, most businesses were characterized as private, and the prices at which they sold their goods or provided their services, as well as many aspects of their employment relations, could not be regulated by the state. Only a small group of businesses "affected with a public interest" could be subjected to such control. Grain elevators, ${ }^{179}$ railroads, ${ }^{180}$ fire insurance, ${ }^{181}$ water utilities, ${ }^{182}$ certain oil pipelines, ${ }^{183}$ public stockyards, ${ }^{184}$ the Chicago Board of Trade, ${ }^{185}$ and a very few other businesses ${ }^{186}$ fell into this select class; all others fell outside it. ${ }^{187}$ Attempts to subject private businesses to such regulation violated parties' freedom to contract, then found in substantive readings of the Due Process Clauses of the Fifth and Fourteenth Amendments. In short, the "formalist" division of the world into public and private realms created a restraint parallel to that imposed on the federal and state governments by the lo$\mathrm{cal} /$ national dichotomy of Commerce Clause jurisprudence.

Now we can return to Commerce Clause jurisprudence, and see the ways in which it interacted with these due process limitations to constrain federal power. Before 1937, the Court upheld national regulation of "local" activities on the ground that they occurred in a stream of interstate commerce on only four occasions. Three of those

178 For a general discussion, see Barry Cushman, Rethinking the New Deal Court ch 3 (Oxford 1998).

179 See, for example, Brass v Stoeser, 153 US 391 (1894); Budd v New York, 143 US 517 (1892); Munn v Illinois, 94 US 113 (1877).

180 See, for example, Chicago \& Grand Trunk Railway Co v Wellman, 143 US 339 (1892); Dow v Beidelman, 125 US 680 (1888); Stone v Farmers' Loan \& Trust Co ("Railroad Commission Cases"), 116 US 307 (1886); Chicago, Milwaukee and St. Paul Railroad Co v Ackley, 94 US 179 (1877); Peik v Chicago and North-Western Railway Co, 94 US 164 (1877); Chicago, Burlington and Quincy Railroad Co v Iowa, 94 US 155 (1877).

181 See, for example, O'Gorman \& Young Inc v Hartford Fire Insurance Co, 282 US 251 (1931); German Alliance Insurance Co v Lewis, 233 US 389 (1914).

182 See, for example, Van Dyke v Geary, 244 US 39 (1917); Spring Valley Water Works v Schottler, 110 US 347 (1884).

183 See, for example, Producers Transportation Co v Railroad Commission of California, 251 US 228 (1920); The Pipe Line Cases, 234 US 548 (1914).

184 See, for example, Tagg Brothers \& Moorhead v United States, 280 US 420 (1930); Stafford v Wallace, 258 US 495 (1922); Cotting v Kansas City Stock Yards Co, 183 US 79 (1901).

185 See Chicago Board of Trade v Olsen, 262 US 1 (1923).

186 See Block v Hirsh, 256 US 135 (1921) (temporary residential rent control in District of Columbia during post-WWI housing crunch); Terminal Taxicab Co v Kutz, 241 US 252 (1916) (certain aspects of taxicab business).

187 See, for example, Williams v Standard Oil Co, 278 US 235 (1929) (petroleum sales); Ribnik v McBride, 277 US 350 (1928) (employment agencies); Tyson \& Brother v Banton, 273 US 418 (1927) (ticket brokerage); Dorchy v Kansas, 264 US 286 (1924) (coal mining industry); Wolff Packing Co v Court of Industrial Relations of Kansas, 262 US 522 (1923) (meat packing industry); Adkins $v$ Children's Hospital of the District of Columbia, 261 US 525 (1923) (hospitals); Adkins $v$ Lyons, 261 US 525 (1923) (hotels); Terminal Taxicab, 241 US at 252 (certain aspects of taxicab business). 
cases involved transactions in a public stockyards; ${ }^{188}$ the fourth involved transactions on the Chicago Board of Trade. ${ }^{189}$ Each of these businesses was affected with a public interest, as the Court made explicit in its opinions. ${ }^{1.0}$ In practice (and in theory), ${ }^{191}$ only those "local" enterprises "affected with a public interest" could be located in a stream of interstate commerce and thereby subjected to federal regulation. Cabined by this due process constraint, the stream of commerce thus cut an exceedingly narrow swath. As far as results were concerned, the stream of commerce cases stood for the proposition that the federal government could regulate transactions in major public stockyards and on the Chicago Board of Trade. Before the mid1930s, Congress simply did not attempt to push the theory any further. Taft's expansive dicta in Stafford must be understood against this backdrop. He was of course not saying that Congress could do whatever it liked. He was instead saying only that Congress could do whatever, in light of the settled understandings of the day, it was likely to do.

Now let's take a similar look at the Shreveport decision. The oftquoted passage states that Congress's

authority, extending to these interstate carriers as instruments of interstate commerce, necessarily embraces the right to control their operations in all matters having such a close and substantial relation to interstate traffic that the control is essential or appropriate to the security of that traffic, to the efficiency of the interstate service, and to the maintenance of conditions under which interstate commerce may be conducted upon fair terms and without molestation or hindrance. As it is competent for Congress to legislate to these ends, unquestionably it may seek their attainment by requiring that the agencies of interstate commerce shall not be used in such manner as to cripple, retard, or destroy it. The fact that carriers are instruments of intrastate commerce, as well as of interstate commerce, does not derogate from the complete and paramount authority of Congress over the latter or preclude the Federal power from being exerted to prevent the intrastate operation of such carriers from being made a means of injury to that which has been confided to Federal care. Wherever the interstate and intrastate transactions of carriers are so related that the government of the one involves the control of the other, it $396-98$

189 See Chicago Board of Trade, 262 US at 33.

190 See id at 40-41; Stafford, 258 US at 516-17.

191 See Cushman, Rethinking the New Deal Court at ch 9 (cited in note 178). 
is Congress, and not the State, that is entitled to prescribe the final and dominant rule, for otherwise Congress would be denied the exercise of its constitutional authority and the State, and not the Nation, would be supreme within the national field.... Congress in the exercise of its paramount power may prevent the common instrumentalities of interstate and intrastate commercial intercourse from being used in their intrastate operations to the injury of interstate commerce. This is not to say that Congress possesses the authority to regulate the internal commerce of a State, as such, but that it does possess the power to foster and protect interstate commerce, and to take all measures necessary or appropriate to that end, although intrastate transactions of interstate carriers may thereby be controlled. ${ }^{192}$

The first thing to be noted about this passage is that Hughes does not ground federal power to regulate rates for intrastate carriage solely in their effect on interstate commerce. Throughout this passage he repeatedly emphasizes that it is the intrastate operations of "agencies" or "instruments" of interstate commerce that are being regulated. That is, he focuses not just on the activity regulated, but also on the interstate nature of the entity regulated. And no one could doubt that the railroads were in fact instruments of interstate commerce, for they actually physically carried people and goods across state lines.

More important, however, is the nature of the regulation in question. Congress could regulate the rates for intrastate carriage, the Court held, because of their relation to rates for interstate carriage. Intrastate carriage competed with interstate carriage; Congress had power to regulate the rates charged for interstate carriage; ergo, Congress had power to regulate the rates charged for intrastate carriage. Of course, Congress had power to regulate rates for interstate carriage (and therefore for intrastate carriage) only because the business of rail carriage was affected with a public interest. ${ }^{193}$ Congress's power to regulate this aspect of interstate carriage, and its corollary power to regulate this aspect of intrastate carriage, was wholly dependent upon the public nature of the business regulated.

Shreveport thus did not grant Congress a license to regulate every kind or even many kinds of intrastate activity that might have an effect (competitive or otherwise) on interstate commerce. Given contemporary Fifth Amendment constraints, it could not have done so

192234 US at 351-53 (emphasis added). This passage, in variousiy edited forms, is reproduced in Cohen and Varat, Constitutional Law at 187 (cited in note 23); in Gunther and Sullivan, Constitutional Law at 167 (cited in note 2); and in Stone, et al, Constitutional Law at 197 (cited in note 1).

193 See notes $179-87$ and accompanying text. 
without simultaneously working a revolution in substantive due process jurisprudence. Instead, Shreveport more modestly recognized federal power to regulate the intrastate rates charged by an interstate business affected with a public interest. So long as the power of Congress to regulate interstate rates remained confined to businesses affected with a public interest, its derivative power to regulate intrastate rates would remain similarly confined. The due process context of Shreveport thus severely constrained the range of its application to intrastate matters. Here again, unless we restore Shreveport to its due process environment, we cannot appreciate its meaning. For if you Shepardize Shreveport, you will find that every case following it from its announcement in 1914 up to the mid-1930s involved regulation of a business affected with a public interest: railroads. ${ }^{\text {st }}$

To be sure, the stream of commerce and Shreveport doctrines offered ways of thinking about the relationship between local and interstate economic activity that threatened to disrupt the symmetry of a jurisprudence grounded in the categories of dormant Commerce Clause doctrine. But until the mid-1930s, that disruption was exceedingly modest in scope. Operating against the background constraints imposed by the Due Process Clause, these "realistic" precedents stood for the proposition that the federal government might regulate a limited set of otherwise local activities: transactions on major public stockyards and grain exchanges, and intrastate rail carriage. Like their "formalist" cousins, these "realistic" decisions identified categories of activity subject to federal control.

The "realistic" cases, then, might have engaged in some pretty big talk; but all of it was uttered from behind the skirts of "formalism." Ripped from their contexts, these utterances appear strikingly "realistic." But they were at best examples of locker room realism.

194 The first Supreme Court decision following Shreveport outside the railroad context was NLRB v Jones \& Laughlin Steel Corp, 301 US 1 (1937) (permitting Congress to regulate labor relations in the steel industry). Beginning in 1934, the lower federal courts began to apply Shreveport in other contexts as well. See, for example, United States v Edwards, 14 F Supp 384 (S D Cal 1936) (fruit packaging); R.C. Tway Coal Co v Glenn, 12 F Supp 570 (W D Ky 1935) (coal mining); United States v Wilshire Oil Co, 9 F Supp 396 (S D Cal 1934) (petroleum refining); United States $v$ Canfield Lumber Co, 7 F Supp 694, 699 (D Neb 1934) (lumber sales); Richmond Hosiery Mills $v$ Camp, 7 F Supp 139 (N D Ga 1934) (hosiery manufacturers); United States $v$ Shissler, 7 F Supp 123, 127 (N D Ill 1934) (milk distribution); United States $v$ Gregg, 5 F Supp 848 (S D Texas 1934). Some examples of railroad regulation cases following Shreveport include Ohio v United States, 292 US 498 (1934); Florida v United States, 292 US 1 (1934); United States v Louisiana, 290 US 70 (1933); Alabama v United States, 279 US 229 (1929); Colorado v United States, 271 US 153 (1926); United States v Village of Hubbard, 266 US 474 (1925); Dayton-Goose Creek Railway Co v United States, 263 US 456 (1924); Railroad Commission of Wisconsin v Chicago, Burlington \& Quincy Railroad Co, 257 US 563 (1922); Illinois Central Railroad Co v Public Utilities Commission of Illinois, 245 US 493 (1918); American Express Co v Caldwell, 244 US 617 (1917). 


\section{REALISM UNBOUND}

The "formalist" restraint on these "realist" formulations dissolved in 1934. In Nebbia $v$ New York, ${ }^{195}$ the Court held that the Due Process Clause demanded "only that the law shall not be unreasonable, arbitrary or capricious, and that the means selected shall have a real and substantial relation to the object sought to be attained." "affected with a public interest" now meant no more than "subject to the exercise of the police power." ject to reasonable exercises of the police power. Accordingly, the majority concluded that "there is no closed class or category of businesses affected with a public interest. ... The phrase 'affected with a public interest' can, in the nature of things, mean no more than that an industry, for adequate reason, is subject to control for the public good." 19

The removal of this due process limitation on congressional legislation opened vast new frontiers for federal regulation. The stream of commerce, previously narrowly channeled, could now overflow its former banks to justify a flood of federal control. And so, for example, attorneys defending the constitutionality of the National Labor Relations Act selected as test cases disputes at manufacturing plants that brought in most of their raw materials from outside the state and shipped their finished products in interstate commerce. These formerly "private" enterprises, they could now plausibly contend, stood astride a stream of interstate commerce." Such broad stream of commerce arguments would continue to figure prominently in argument, commentary, and judicial decision throughout the late $1930 \mathrm{~s}^{200}$

Yet Nebbia's ramifications for Commerce Clause jurisprudence were confined to those contexts in which the due process limitation had constrained the scope of a Commerce Clause formulation. Characterizing a previously "private" business as "public," for example, did

195291 US 502 (1934).

196 Id at 525.

197 Id at 533. For an extensive discussion of Nebbia, its antecedents, and its ramifications, see Cushman, Rethinking the New Deal Court (cited in note 178).

198 Nebbia, 291 US at 536.

199 See NLRB v Friedman-Harry Marks Clothing Co, 301 US 58, 72 (1937) (applying NLRA to clothes manufacturing company using wholly imported cloth); NLRB $v$ Fruehauf Trailer Co, 301 US 49 (1937) (applying NLRA to trailer manufacturers receiving most parts from out-of-state suppliers and shipping most goods in interstate commerce); NLRB v Jones \& Laughlin Steel Corp, 301 US 1 (1937) (applying NLRA to steel industry). For a discussion of the selection of the test cases, and the briefing and arguing of those cases on the current of commerce theory, see Cushman, Rethinking the New Deal Court at 162-68 (cited in note 178); Peter Irons, The New Deal Lawyers 254-72 (Princeton 1982).

200 For discussion of the role that the stream of commerce doctrine played in the litigation of the Labor Board Cases of 1937 and in NLRB v Fainblatt, 306 US 601, 605-06 (1939), see Cushman, Rethinking the New Deal Court at 162-82, 184-89 (cited in note 178). 
not change the fact that the activity was conducted at a terminal of, rather than amidst, a stream of interstate commerce. Such activities had lain outside federal regulatory competence not merely because they were "private," but because they were essentially "local"-and Nebbia did nothing to alter that status. Thus, while the abandonment of the public/private limitation in due process doctrine allowed much broader play to the "realist" Commerce Clause formulations which it had previously constrained, "realism's" emancipation did not herald "formalism's" immediate demise. As the opportunities presented by Nebbia channeled congressional regulation into new forms that tapped the expanded range of the Shreveport doctrine, it became decreasingly necessary to confront the continuing vitality of "formalistic" doctrinal formulations. For a brief period after 1934, then, the Knight and the Nebbia-enhanced "realist" lines of authority could continue to enjoy an increasingly strained but nonetheless manageable coexistence.

Thus, even a swollen current of commerce could not support the constitutionality of the Live Poultry Code of the National Industrial Recovery Act. Once the poultry arrived at the Schechters' Brooklyn slaughterhouse, "it had come to a permanent rest within the State." As it would not continue in interstate commerce, the stream of commerce cases were "not applicable." the continuing thrall in which the Court's affirmative Commerce Clause jurisprudence was held by the categories developed in service of the Clause's negative implications. Ten years earlier, the Court had turned back a dormant Commerce Clause challenge to a New York statute regulating the sale of kosher meats. The Court had found that the meat had come to a permanent rest within the state and was held solely for local disposition and use. Accordingly, it was subject to state regulation, notwithstanding the fact that the regulation might "incidentally affect interstate commerce." Such regulation imposed no "direct burden" on interstate commerce..$^{202}$ State regulations of local kosher butchering affected interstate commerce only "incidentally" and were accordingly constitutional; a fortiori, the wages, hours, and sales practices of local kosher butchers affected interstate commerce only "indirectly" and were beyond the reach of federal regulation. ${ }^{203}$

201 Schechter Poultry, 295 US at 543.

202 Hygrade Provision Co v Sherman, 266 US 497, 502-03 (1925).

203 Even Learned Hand, the paragon of judicial restraint, see Gerald Gunther, Learned Hand: The Man and the Judge (Knopf 1994), could not avoid the conclusion that the wage and hour regulations exceeded federal power. See United States y A.L.A. Schechter Poultry Corp, 76 F2d 617, 624-25 (2d Cir 1935) (Hand concurring) ("[T]he regulation of the hours and wages of all local employees, who turn the fowls into merchantable poultry after they have become a part of the domestic stock of goods, seems to me so different in degree as to be beyond the line [of congressional power]."). 
As Justice Sutherland's opinion for the majority pointed out, Carter Coal presented the same question, but at the opposite terminal of the current of commerce. "In the Schechter case," he wrote, "the flow had ceased. Here it had not begun. The difference is not one of substance. The applicable principle is the same." ${ }^{204}$ In an opinion littered with citations to and quotations from dormant Commerce Clause cases, the Court held that the wages, hours, and other employment conditions of employees engaged in mining coal were "local" matters beyond the reach of federal authority. ${ }^{205}$ After all, the Court had recently upheld state taxation or regulation of coal mining, iron mining, oil production, and production of electricity against claims that it violated the dormant Commerce Clause. ${ }^{206}$ What was sauce for the goose was sauce for the gander.

Yet portions of the decision pointed out new avenues of regulatory opportunity. The members of the Carter majority invalidated the price-fixing provisions of the Act solely on the grounds that they were inseparable from the offending labor provisions. ${ }^{207}$ They therefore did not dispute Chief Justice Hughes when, writing separately, he maintained that those provisions, if considered separately, were valid. Relying on Nebbia, the Chief Justice maintained, "We are not at liberty to deny to the Congress, with respect to interstate commerce, a power commensurate with that enjoyed by the States in the regulation of their internal commerce." state transactions may not be regulated by the states. They must therefore be subject to the power of the nation unless they are to be withdrawn altogether from governmental supervision." ${ }^{20}$ Nor did the majority dispute Cardozo's contention that the federal government possessed power to regulate the price of intrastate sales of coal as well. Relying explicitly on Shreveport and its progeny, Cardozo maintained that " [w]ithin rulings the most orthodox, the prices for intrastate sales of coal have so inescapable a relation to those for interstate sales that a system of regulation for transactions of the one class is necessary to give adequate protection to the system of regulation adopted for the other.",210

204 Carter Coal, 298 US at 306.

205 Id at 308.

206 Champlin Refining Co v Corporation Commission of Oklahoma, 286 US 210 (1932);

Utah Power \& Light Co v Pfost, 286 US 165 (1932); Oliver Iron Mining Co v Lord, 262 US 172

(1923); Heisler v Thomas Colliery Co, 260 US 245 (1922).

207 Carter Coal, 298 US at 312-16.

208 Id at 319.

209 Id at 326 (citation omitted). Cardozo similarly maintained that Nebbia dispelled any Fifth Amendment doubts as to the power of Congress to regulate the price of coal. Id at 330-32.

210 Id at 328-29 (emphasis added). Cardozo contended that the company had as yet sustained no injury under the labor provisions of the Act, and accordingly would have dismissed its 
Such a ruling would certainly not have been orthodox before Nebbia. The coal business had up to that time been considered a private business not affected with a public interest. ${ }^{211}$ The Fifth Amendment would therefore have precluded federal regulation of the price at which coal was sold in interstate commerce. Unable to regulate the price of such interstate sales, Congress could not have looked to Shreveport for authority to regulate the price of intrastate sales. But in 1934, the lower federal courts began linking Shreveport and Nebbia in cases upholding federal regulation of intrastate prices. ${ }^{212}$ Congress also quickly grasped Nebbia's implications. Drawing now on the line of authority that held that "buying and selling and the transportation incidental thereto constitute commerce, ${ }^{213}$ the national legislature changed its strategy to one of regulating interstate marketing rather than local production. The result was a new wave of statutes extending federal control over intrastate transactions.

In the spring of 1937, Congress enacted a new Bituminous Coal Conservation Act. Congress no longer sought to regulate labor relations and conditions in the coal business, but it did still seek to control both the interstate and the intrastate prices of coal. Moreover, it did so, following Cardozo's Carter dissent, "within rulings the most orthodox." The bill's sponsors reasoned that Congress could regulate sales in interstate commerce, and the Due Process Clause no longer precluded that regulation including a specification of the price. Moreover, intrastate coal competed with interstate coal; accordingly, following Shreveport, it was necessary and proper for Congress to regulate the price of coal sold intrastate. ${ }^{214}$ When the statute was challenged in 1940, only Justice McReynolds dissented from the opinion upholding it. ${ }^{215}$

In 1938, Congress sought to support and stabilize prices in specified agricultural commodities by limiting the amount that producers could market. When the provisions of the Agricultural Adjustment Act of 1938 regulating tobacco sales were challenged in 1939, the Court upheld them as a legitimate regulation of interstate marketing. Yet the assigned marketing quotas also necessarily limited the amount of tobacco that a producer could sell in intrastate commerce as well.

attack on those provisions on ripeness grounds. As to the validity or invalidity of those provisions, Cardozo insisted, "No opinion is expressed either directly or by implication as to those aspects of the case." Id at 324.

211 See Dorchy $v$ Kansas, 264 US 286, 289 (1924) (forbidding state regulation of labor relations at a mine).

212 See, for example, United States v Shissler, 7 F Supp 123, 126-27 (N D Ill 1934) (permitting regulation of milk distributors); United States $v$ Spotless Dollar Cleaners, 6 F Supp 725, 730 (S D NY 1934).

213 Knight, 156 US at 14.

214 See Cushman, Rethinking the New Deal Court at 193-96,204-05 (cited in note 178).

215 See Sunshine Anthracite Coal Co v Adkins, 310 US 381 (1940). 
The Court responded by turning to Shreveport. "[A]t least two-thirds of all flue-cured tobacco sold at auction warehouses is sold for immediate shipment to an interstate or foreign destination," wrote Justice Roberts. "In markets where tobacco is sold to both interstate and intrastate purchasers it is not known, when the grower places his tobacco on the warehouse floor for sale, whether it is destined for interstate or intrastate commerce. Regulation to be effective, must, and therefore may constitutionally, apply to all sales."216

Similarly, the Agricultural Marketing Agreement Act authorized the Secretary of Agriculture to set minimum prices at which processors could purchase certain agricultural commodities, such as milk, from producers. Here again, the Act's sponsors reasoned that Congress's power to regulate interstate buying and selling included the power to set the price of such interstate sales. Observing that large metropolitan markets included both interstate and intrastate milk, the Act's backers reasoned that the intrastate milk competed with interstate milk in the same way that intrastate rail carriage had competed with its interstate counterpart in Shreveport. In order for the fixing of minimum producer prices for interstate milk to be effective, they concluded, equivalent prices for the intrastate milk with which it competed would have to be established as well. The Court accepted these arguments, upholding the Act in United States $v$ Rock Royal Cooperative, Inc $^{217}$ and H.P. Hood \& Sons, Inc v United States ${ }^{218}$ in 1939. And in 1942, the Court relied heavily on Shreveport's competition doctrine when it upheld federal regulation of the price of milk that was purchased in the state of its production and sold solely within the state. The Wrightwood Dairy didn't even handle interstate milk. It was not an "agency" or "instrument" of interstate commerce; it was not even engaged in interstate commerce. Yet the fact that its intrastate milk competed with interstate milk was sufficient to warrant federal regulation of its prices. ${ }^{219}$

By the spring of 1942 , Court watchers were reeling. Nebbia's liberation of the Shreveport doctrine unleashed a federal regulatory power that appeared competent to address almost all of the nation's economic ills. Editors at the Columbia Law Review, for example, rec-

216 Mulford $v$ Smith, 307 US 38, 47 (1939). For a discussion of the legislative history of the Act and its defense before the Court, see Cushman, Rethinking the New Deal Court at 196-203 (cited in note 178). The Court relied in part on Currin v Wallace, 306 US 1, 11 (1939), in which the Court had upheld provisions of the Tobacco Inspection Act of 1935, relying on Shreveport in subjecting both interstate and intrastate sales of tobacco to the Act's inspection provisions. See Cushman, Rethinking the New Deal Court at 190-93 (cited in note 178).

217307 US 533 (1939).

218307 US 588 (1939).

219 United States $v$ Wrightwood Dairy, 315 US 110 (1942). See Cushman, Rethinking the New Deal Court at 203-07 (cited in note 178). 
ognized that the logic of Shreveport's competition doctrine had no obvious limits:

Since, theoretically, the standard of [the milk cases] could make interstate and intrastate commerce coextensive, as every product on the market competes with every other for a portion of the total demand, the obvious problem in applying the new concept is to discover within what bounds the effects of actual competition will be given legal significance. ${ }^{20}$

"The implications of the 'competition' doctrine, if carried to their logical extreme, would result in a complete withdrawal of the Supreme Court from its position as a check upon Congressional action under the commerce clause."21 Members of the nation's highest court would soon be thinking along similar lines.

\section{THE END OF REALISM}

The removal of the due process limitations that had defined the scope of the stream of commerce and Shreveport doctrines thus had far-reaching ramifications for the ambit of federal regulatory power. By focusing its recovery efforts on the marketing rather than the production of coal and farm commodities, Congress was able to address the problems of the energy and agricultural sectors with programs that could withstand judicial scrutiny. But the constitutional success of these initiatives papered over lingering "formalist" restraints on federal power. For as Carter Coal had demonstrated, Nebbia had done nothing to bring productive activities located at the source of the stream of commerce within the domain of federal regulation. In fact, as intracurial records illustrate, the Justices continued to analyze regulations of production within the categorical framework derived from the Court's dormant Commerce Clause jurisprudence. But Congress was not long content to regulate marketing alone, and so the inevitable confrontation between the "formalist" and the unshackled "realist" styles came in the spring of 1942. Rather than awarding victory to either interpretive mode, however, the Court selected a third option that reoriented both affirmative and dormant Commerce Clause jurisprudence.

220 Recent Decisions: Constitutional Law-Effect of Competition of Intrastate Commerce on Interstate Commerce as Justifying Regulation of Former, 42 Colum L Rev 694, 696 (1942). See also Constitutional Law-Interstate Commerce Clause-Agricultural Marketing Agreement Act of 1937, 8 U Pitt L Rev 139, 140 (1942) ("Conceivably any wholly intrastate activity competes with a similar interstate activity.").

22142 Colum L Rev at 699 (cited in note 220).

222 See text accompanying notes 207-11. 
The amended Agricultural Adjustment Act of 1938 authorized the Secretary of Agriculture to allocate among the nation's farmers the number of acres of certain staple crops they would be permitted to market without penalty. Provisions of the Act penalized production of crops on acreage in excess of that allotted, unless the excess was stored in compliance with regulations promulgated by the Secretary. Roscoe Filburn was penalized for violating these provisions. Filburn had marketed the harvest from his allotted acreage, but rather than storing the excess as prescribed, he had reserved all of his surplus wheat for use and consumption on his own farm. The government contended that the prohibition on production of wheat for home consumption was a regulation of "marketing," "23 but Justice Robert Jackson, to whom the opinion was assigned, saw it as a regulation "of production not for commerce either actually or in contemplation," ${ }^{24}$ an activity "neither interstate nor commerce."2s

After initial argument in early May of $1942,{ }^{26}$ Jackson prepared two draft opinions. Each of them took a "realistic," empirical approach to the case. And in each the Court would have remanded the case to the trial court for additional factual findings through which the Court might determine whether the requisite effect on interstate commerce existed. ${ }^{27}$

In the first draft Jackson remarked that "[t]he stipulated factsthe only evidence in the case-are of no material assistance in determining the validity of the Government's contention.... The constitutional issue involved is of the greatest magnitude, and we are of opinion that we should not pass upon it in the present state of the record, without the benefit of findings and consideration by the court below of a full presentation of the controlling economic facts relied upon."2s

In the second draft Jackson again maintained that "the record in this case does not afford sufficient basis for a decision under the commerce clause." "Perhaps," he wrote,

[W]e could assume in the present case without proof that if a farmer is not permitted to feed his own wheat to his livestock he

223 See Wickard v Filburn, 317 US 111, 119 (1942).

224 Memorandum for Mr. Costelloe, Re Wickard Case, 1 (June 19, 1942), Box 125, Jackson MSS, LC ("Memorandum for Costelloe I") (copy on file with author).

225 Robert H. Jackson to Harlan Fiske Stone, Re Wickard case, 1 (May 25, 1942), Box 125, Jackson MSS, LC ("Wickard letter I") (copy on file with author). See also Wickard, 317 US at 119-20.

226 Wickard, 317 US at 111.

227 Opinion draft, Wickard v Filburn, No 1080 (undated) Box 125, Jackson MSS, LC ("Wickard draft I") (copy on file with author); Opinion draft, Wickard v Filburn, No 1080 (May 22, 1942), Box 125, Jackson MSS, LC ("Wickard draft II") (copy on file with author).

228 Wickard draft I at 3 (cited in note 227).

229 Wickard draft II at 7 (cited in note 227). 
will be forced into the market as a feed buyer and thereby help swell the volume and sustain prices of the interstate market, or perhaps we should as reasonably assume that he will be forced into the market as a livestock seller. So, also, might we assume that if he and his family are forbidden to eat his home-grown wheat, he might be forced into the market as a buyer of wheat products or perhaps we should as reasonably expect him to turn for sustenance to other products.

This, of course, was the rationale upon which a unanimous Court would ultimately uphold the penalty. But in the spring of 1942 there was not yet even a majority that was prepared to embrace it. "Whether the production of wheat for consumption on the farm does have a substantial effect upon interstate commerce by taking such a producer out of the consumer market or by the possibility that the wheat so produced may actually be put upon the market directly or by sale of stock to which it is fed," Jackson wrote, "are far from clear on the record and the legislative history presented." "[T] "231 stipulated evidence in the record-the only general evidence in the casetouches upon it in only the most general sort of way."2:2 And more than theoretical economic speculation was required. "To establish the power of Congress over intrastate activity it is of course not sufficient simply to spell out some plausible relationship between such activity and interstate commerce." Instead, empirical verification was essential: "The power to enter upon the state domain is justified only by $a$ state of facts showing that the intrastate activities sought to be reached are of such quality and substantiality that what would otherwise be an intrusion is proper for the protection and effective exercise of a granted federal power." 234 In Chicago Board of Trade v Olsen, ${ }^{235}$ for example, "It was shown that [intrastate transactions in grain futures] had as a matter of fact exercised great influence upon the price of grain moving in interstate commerce." ${ }^{266}$ As Jackson wrote to Chief Justice Stone,

230 Id at 12 . The first draft had outlined the theory in more rudimentary form: "It is of course true that if the farmer is not permitted to feed his own produce to his livestock, he may be forced into the market as a buyer of produce in order to promote the produce market; or he may be forced into the market as a seller of his livestock. And if forbidden to eat his wheat, so also may he turn for sustenance to corn pone, grits or hominy." But here again Jackson had rejected this contention due to inadequate empirical support. Wickard draft I at 3 (cited in note 227).

231 Wickard draft II at 12 (cited in note 227).

232 Id.

233 Id at 9-10.

234 Id at 11-12 (emphasis added).

235262 US 1 (1923) (holding that the Board of Trade was in the stream of interstate commerce):

236 Wickard draft II at 10 (cited in note 227) (emphasis added). 
The Constitution drew a line between state and federal power and here the Congress wants to cross that line admittedly. I suppose that before we give it our approval there must be some finding that it is warranted by facts and conditions. Otherwise, the federal compact was pretty meaningless if Congress is to be sole judge of the extent of its own commerce power. As you have well pointed out in the Darby case, sometimes the Court has been required to determine the facts that carry federal power across the line; sometimes administrative bodies do it; sometimes Congress has done it-but only, I think, where the effect was obvious to the naked judicial eye. ${ }^{237}$

Jackson thus insisted that it was "the function of the courts to determine whether the particular activity regulated or prohibited is within the reach of federal power."23s The legislative history and the facts on the record did not demonstrate to Jackson's satisfaction that the growth of wheat for home consumption had a substantial effect on interstate commerce, and he and his brethren were not prepared to take the government's word for it. . $^{29}$ The absence of such factual findings, Jackson concluded, "have left us without adequate materials for confident judgment that an affirmative answer to the question of power would not 'effectively obliterate the distinction between what is national [and what is local] and create a completely centralized government.","200

Justices Roberts, Frankfurter, Murphy, and Byrnes each agreed to this draft. ${ }^{241}$ At a subsequent conference, however, the Justices reached a tentative agreement that the case be set for reargument rather than remanded, ${ }^{22}$ and Jackson prepared an order restoring the case to the docket for reargument the following October ${ }^{243}$ Moreover, that order asked for no additional facts to support the contention that Filburn's activities affected interstate commerce substantially. The case would now be decided on the existing record, which Jackson and his colleagues had so recently found so unilluminating. This decision to order reargument rather than to remand the case for further factual findings foretold the abandonment of a court-centered, empirical methodology in Commerce Clause jurisprudence.

237 Wickard letter I at 1 (cited in note 225) (emphasis added) (mentioning United States v Darby, 312 US 100 (1941)).

238 Wickard draft II at 12 (cited in note 227) (emphasis added).

239 Id.

240 Id at 13 (alteration added) (citing Jones \& Laughlin, 301 US at 1).

241 Justice Reed asked to be disqualified. See returns of Wickard draft $I$.

242 Memorandum in Re: No 1080-Wickard v Filburn, Box 125, Jackson MSS, LC (copy on file with author).

243 Robert H. Jackson, Memorandum for the Members of the Court, Re: No 1080-Wickard $v$ Filburn (undated), Box 125, Jackson MSS, LC (copy on file with author). 
That summer Jackson wrote two memoranda to his law clerk in which he worked his way through the Commerce Clause issue presented. Under these circumstances, wrote Jackson, there were three possible holdings. First, the Court might hold that "production and consumption not for commerce is exclusively within the control of the state.", That, he observed, would have been consistent with the "formalistic" Knight line of cases. Second, the Court might hold that local production "is normally within the control of the state but is transferred to federal control upon judicial findings that it is necessary to protect exercise of the commerce power."24s That, he noted, would have been consistent with such "realistic" cases as Stafford and Shreveport, which stood for the proposition that "matters normally within the political domain of the states might be transferred to federal control because of their economic relationships." ${ }^{2+5}$ Indeed, this appears to have been the theory upon which Jackson and his colleagues had in May thought the case should be decided. The difficulty had been the absence of facts that would have supported such judicial findings. Jackson's third possible holding, however, was unprecedented: "That it is normally within the control of the state but that it is transferred to federal control upon a mere Congressional assumption of control.".".t7

Before the Shreveport case was decided, Jackson thought, there would have been no doubt that the first holding was the appropriate one..$^{2+4}$ After all, production was production. But Shreveport had introduced a new approach, "a break with localistic and legalistic thinking," admitting economic data as a factor in determining the scope of the commerce power. ${ }^{299}$ But this approach too had its difficulties: "Economic effects are exceedingly difficult to trace beyond immediate effects." "A difficulty which may not have been foreseen in adopting economic, in addition to legal, standards for the measurement of the commerce power," wrote Jackson, "grows out of the indefiniteness of economic lines. The political lines are definitely drawn but economic lines are not." "The same economic forces which made the political pattern of a subdivided nation inept for regulatory purposes made all

244 Memorandum for Costelloe I at 1 (cited in note 224).

245 Id (emphasis added).

246 Id at 2.

247 Id at 1.

248 Id.

249 Wickard v Filburn, Memorandum by Mr. Justice Jackson, 10 (undated), Box 125, Jackson MSS, LC ("Memorandum by Jackson") (copy on file with author).

250 Memorandum for Costelloe I at 2 (cited in note 224).

251 Memorandum for Mr. Costelloe, Re Wickard Case, 12 (July 10, 1942), Box 125, Jackson MSS, LC ("Memorandum for Costelloe II") (copy on file with author). 
boundaries based on economic facts vague and blurred."252 Trying to cabin Shreveport's notion of competition was like trying to nail jelly to a wall.

The comparatively simple, and perhaps oversimplified, concepts of the law lose their validity when applied to economic data. It has been an easy thing to say that the power to regulate commerce included the power to protect that commerce against competition, for the legal concept of competition was a fairly definite and simple one. But what is competition in an economic sense? While competition in a legal sense would arise only between men dealing in the same kind of goods and hence attempting to fulfill the same customer desires, the economic concept of competition might be very much broader and more difficult of ascertainment. In the economic sense, fuel oil competes with coal. Both are rivals of electricity, and all three of them are competitors with every other commodity in the market for the consumer's dollar.

The Court's attempts "to ascertain legal standards for weighing economic facts and for applying them to the commerce power" had been "neither consistent nor well defined." employed in Schechter and "again emphasized" in Jones \& Laughlin was a "legal phrase[ ] of limitation" having "almost no value in weighing economic effects." ${ }^{255}$ The Court had yet to formulate a standard with any "real value.".

The failure to develop adequate standards for determining the circumstances under which "local" activities affected interstate commerce sufficiently to support federal regulation led Jackson to abandon the effort altogether. In light of the complexity of causation in the modern American economy, ${ }^{257}$ he saw traditional formulae for distinguishing "local" from "national" economic activity as ropes of sand. "At what point these effects have enough vitality to confer federal jurisdiction and at what point they have passed outside it, we have no

252 Id at 13.

253 Id at 12-13.

254 Id at 13. "[T] to determine what effects upon interstate commerce are adequate to confer jurisdiction on the federal government and what are not." Id at 14.

255 Id at 14-18.

256 Memorandum for Costelloe I at 3 (cited in note 224). See also Memorandum for Costelloe II at 13-18 (cited in note 251).

257 "Economic effects seem almost as persistent as physical force which, it is said, once exerted is never lost. An economic impulse continues indefinitely and may be overcome or its identity lost but it is too illusive and subtle for tracing out in legal proceedings. First impacts shade off in force as they expand, like the concentric rings caused by throwing a stone in the water." Memorandum for Costelloe II at 15 (cited in note 251). 
standards to determine, and I am not at all sure of our capacity to invent such a standard that would have any validity upon the immediate case to which it is applied." "Is "In such a state of affairs," he remarked, "the determination of the limit is not a matter of legal principle, but of personal opinion; not one of constitutional law, but one of economic policy.,2ss

It was this realization that led Jackson to turn from his second possible holding to his third. ${ }^{230}$ It was emphatically the duty of the judiciary to say what the law of the Constitution was; but economic policy was a matter for the legislature, not for the courts. "We have all but reached an era in the interpretation of the commerce clause of candid recognition that we have no legal judgment upon economic effects which we can oppose to the policy judgment made by Congress in legislation," ${ }^{261}$ he wrote. "It is perhaps time that we recognize that the introduction of economic determinism into constitutional law of interstate commerce marked the end of judicial control of the scope of federal activity.",262

Adopting the third alternative had the virtue of making this and all future commerce power cases easy. Neither additional factual information, nor a standard by which to evaluate it, nor its evaluation under such a standard was any longer necessary. The fact that Congress had enacted the statute was alone sufficient proof of its constitutionality.

Congress has seen fit to regulate small and casual wheat growers in the interest of large and specialized ones. It has seen fit to extend its regulation to the grower of wheat for home consumption. Whether this is necessary, whether it is just, whether it is wise, is not for us to say. We cannot say that there is no economic relationship between the growth of wheat for home consumption and interstate commerce in wheat. As to the weight to be given the

258 Id.

259 Id.

260 "All of this raises seriously the question whether the extent of power under the commerce clause is appropriate for judicial decision and brings us to the question of whether Congress by determining what is 'appropriate' to its own regulatory schemes may in effect define the extent of its own power under the commerce clause." Memorandum for Costelloe I at 3 (cited in note 224).

261 Memorandum for Costelloe II at 15 (cited in note 251). "Once breaking away from a legalistic interpretation of the Constitution and adopting an economic basis, it becomes impossible for this Court to maintain a position that a subject which Congress and the President regard as appropriate for regulation is not in fact appropriate, or that one where Congress and a President perceive a relationship and an effect is in fact nonexistent." Id at 17.

262 Memorandum for Costelloe I at 6 (cited in note 224). 
effects, we have no legal standards by which to set our own judgment against the policy judgment of Congress. ${ }^{233}$

Paraphrasing a famous remark that Chief Justice Hughes had made while Governor of New York, Jackson maintained that Filburn's growth of wheat for home consumption "is within the federal power to regulate interstate commerce, if for no better reason than that the commerce clause is what the Congress says it is.",264 That may have been "pragmatic," but it certainly was not "empiric."

Jackson's opinion for a unanimous Court did offer an extended presentation of data concerning the economics of the worldwide wheat market. ${ }^{2.5}$ But these data were not the fruits of any additional empirical work by the parties or the Court. They were drawn from the stipulation of facts that the parties had filed before the first argument, and were contained in the record that Jackson's May draft opinions had found so unsatisfying. Moreover, as Jackson had noted in his May drafts, these data were only vaguely relevant to the issue facing the Court: the effect of growth of wheat for home consumption on interstate commerce in wheat. And now the mode of analysis Jackson had rejected in May because it lacked adequate support in the record became the theory on which the opinion turned. Growth of wheat for home consumption, Jackson explained, reduced the demand for wheat sold in interstate commerce and thereby reduced the price at which such wheat was sold. Because Congress was empowered to regulate the prices at which goods were sold in interstate commerce, it could regulate those activities that affected such prices. Though Filburn's wheat-growing activities taken alone might have little or no effect on the price of wheat, his activities, "taken together with that of many others similarly situated,", might have a substantial effect.

Did the record support judicial findings of such an effect? Here Jackson finessed the issue. "This record," he wrote, "leaves us in no doubt that Congress may properly have considered that wheat consumed on the farm where grown, if wholly outside the scheme of regulation, would have a substantial effect in defeating and obstructing its purpose to stimulate trade therein at increased prices." ${ }^{267}$ The record did not leave the Court with no doubt that wheat consumed on the farm did in fact have such an effect-Jackson had expressed just such doubts for a majority of his colleagues in his May drafts. However, the

263 Memorandum for Costelloe II at 20 (cited in note 251). "Congress has said that Igrowth of wheat for home consumption] ... is [ ] appropriate to regulation, and the Court is without power to gainsay this Congressional determination." Id at 22.

264 Id at 22.

265 Wickard, 317 US at 125-27.

266 Id at 127-28.

267 Id at 128-29. 
record did leave the Justices with no doubt that "Congress may properly have considered" that it would have such an effect. In other words, a record that had been utterly inadequate for an empirical, $j u$ dicial assessment of the effect was perfectly adequate for a legislative determination. The Court was no longer independently passing on whether Congress's determination was correct; it was merely finding that what Congress had "considered" was "proper." Indeed, a close reading of the Wickard opinion leaves one in doubt whether the Court really articulated any judicially enforceable test of the commerce power at all. ${ }^{28}$

This conclusion is reinforced by the wording of a memorandum that Jackson circulated among the Justices. Referring to "the presumption of constitutionality which is raised by Congressional action,",269 Jackson wrote:

We cannot say from anything in this record that the effect on commerce from the multiplication of individually trifling growers of wheat for home consumption is not substantial.

[W] ground our decision on the realities disclosed, which afford no basis for judicial denial to Congress of the power to extend its regulation to the production of wheat not intended for commerce or sale. ${ }^{200}$

Nowhere did Jackson explain or even suggest what would have afforded a basis for such a judicial denial. The presumption of constitutionality embraced by Jackson appeared to place upon the party challenging the statute the burden of proving that the activity regulated produced in the aggregate no substantial effect on interstate commerce. As proof of such a negative would be virtually impossible, the presumption of constitutionality was effectively conclusive. Congress became both the primary and the final judge of the statute's constitutionality.

Consider finally a letter in which Jackson attempted to explain the Court's decision to his friend Sherman Minton. "I really know of no place," Jackson confessed, "where we can bound the doctrine of competition as expounded in the Shreveport, the Wrightwood, and the Wickard cases. I suppose that soy beans compete with wheat, and buckwheat competes with soy beans, and a man who spends his money for corn liquor affects the interstate commerce in corn because

268 See Cushman, Rethinking the New Deal Court at 220-22 (cited in note 178).

269 Memorandum by Jackson at 10 (cited in note 249).

270 Id at 12-13. 
he withdraws that much purchasing power from that market." And so the jig was up. "If we were to be brutally frank," he wrote, "I suspect what we would say is that in any case where Congress thinks there is an effect on interstate commerce, the Court will accept that judgment. All of the efforts to set up formulae to confine the commerce power have failed. When we admit that it is an economic matter, we pretty nearly admit that it is not a matter which courts may judge."

The Court would continue to judge the impact of state and local regulations on interstate commerce, however. The national political process was, in Jackson's view, sufficient to safeguard the states from congressional overreaching. ${ }^{273}$ But the political process was not sufficient where state or local legislation was at issue. As Justice Stone had put it in South Carolina Highway Department v Barnwell Brothers. ${ }^{274}$

State regulations affecting interstate commerce, whose purpose or effect is to gain for those within the state an advantage at the expense of those without, or to burden those out of the state without any corresponding advantage to those within, have been thought to impinge upon the constitutional prohibition even though Congress has not acted.... Underlying the stated rule has been the thought, often expressed in judicial opinion, that when the regulation is of such a character that its burden falls principally upon those without the state, legislative action is not likely to be subjected to those political constraints which are normally exerted on legislation where it adversely affects some interests within the state. ${ }^{275}$

\footnotetext{
271 Robert H. Jackson to Sherman Minton 1-2, (Dec 21, 1942), Box 125, Jackson MSS, LC.

272 Id at 1.

273 As he wrote privately to his clerk,
}

The same people elect the state and the federal officers. The interests represented by the two are the same. The people can punish excess or irresponsibility in the use of the commerce power by Congressmen. It does not seem likely that the people would send men to Washington to take away powers which they elect state officers to exercise.

..

Federal power can, of course, discredit itself by attempting more than is just or can break down attempting more than it has capacity to organize or administer. Its excesses and irresponsibilities it must answer for at the polls.

Memorandum for Costelloe I at 6-7 (cited in note 224).

274303 US 177 (1938).

275 Id at 184-85 $\mathrm{n} 2$. Of course, as Stone noted, the redress need not come from the state legislature: "Congress, in the exercise of its plenary power to regulate interstate commerce, may determine whether the burdens imposed on it by state regulation, otherwise permissible, are too great, and may, by legislation designed to secure uniformity or in other respects to protect the national interest in commerce, curtail to some extent the state's regulatory power." Id at 189-90. Jackson, who remained skeptical of the prospects for congressional intervention, defended con- 
Just as the Court continued throughout the late 1930s to uphold federal regulation of activities having a "direct effect upon interstate and foreign commerce,", stitutionality of state legislation by determining whether it affected interstate commerce only "incidentally or indirectly." But once Wickard abandoned direct and indirect effects as analytic categories in the autumn of $1942,{ }^{278}$ their retention in dormant Commerce Clause jurisprudence became anomalous. If "direct" and "indirect" were unsatisfactory descriptions of the effects of activities on interstate commerce, then surely they were equally unsatisfactory descriptions of the effects of state and local regulations upon such commerce.

Moreover, Wickard created even larger problems for dormant Commerce Clause jurisprudence. Local activities such as production had previously affected interstate commerce only "in'directly," and had accordingly been subject to state and local regulation. Now, to use the older vocabulary, even those activities affected interstate commerce sufficiently "directly" to warrant federal regulation. State and local regulation of those activities would now presumably affect interstate commerce "directly" as well. But state and local regulations affecting such commerce "directly" had long been held to transgress the implicit limitations of the Commerce Clause. Were the growth of federal power not to obliterate state and local regulatory authority by implication, dormant Commerce Clause jurisprudence would have to be placed upon a new footing. It would have to be decoupled from its affirmative counterpart, to abandon the categories the two had shared, and regulatory authority over such matters would have to become concurrent.

This is precisely what happened later that same term in Parker $v$ Brown. ${ }^{279}$ The case involved provisions of the California Agricultural Prorate Act regulating contracts between raisin producers and local processors. Chief Justice Stone, who had earlier criticized the direct/indirect distinction in a case involving foreign commerce, ${ }^{250}$ wrote the opinion sustaining the regulation against a dormant Commerce

tinued judicial scrutiny. State and local restraints on interstate commerce, he wrote, were "individually too petty, too diversified, and too local to get the attention of a Congress hard pressed with more urgent matters." Duckworth v Arkansas, 314 US 390, 400 (1941) (Jackson concurring).

276 Santa Cruz Fruit Packing Co v NLRB, 303 US 453, 469 (1938) (permitting regulation of labor dispute regarding workers in shipping industry).

277 Milk Control Board v Eisenberg Farm Products, 306 US 346, 351 (1939) (upholding state regulation of prices paid to milk producers by in-state dealers).

278317 US at 124-25.

279317 US 341 (1943).

280 See Di Santo v Pennsylvania, 273 US 34, 43-45 (1927) (Stone dissenting) (arguing against the invalidation of a state law requiring agents selling tickets for foreign boat travel to obtain licenses from the state). 
Clause challenge. Stone noted that the regulation could have been sustained employing conventional analysis:

This distinction between local regulation of those who are not engaged in commerce, although the commodity which they produce and sell to local buyers is ultimately destined for interstate commerce, and the regulation of those who engage in the commerce by selling the product interstate, has in general served, and serves here, as a ready means of distinguishing those local activities which, under the Commerce Clause, are the appropriate subject of state regulation despite their effect on interstate commerce. ${ }^{21}$

"But," Stone continued,

[C]ourts are not confined to so mechanical a test. When Congress has not exerted its power under the Commerce Clause, and state regulation of matters of local concern is so related to interstate commerce that it also operates as a regulation of that commerce, the reconciliation of the power thus granted with that reserved to the state is to be attained by the accommodation of the competing demands of the state and national interests involved.

Such regulations by the state are to be sustained, not because they are "indirect" rather than "direct" [citing Wickard], not because they control interstate activities in such a manner as only to affect the commerce rather than to command its operations. But they are to be upheld because upon a consideration of all the relevant facts and circumstances it appears that the matter is one which may appropriately be regulated in the interest of the safety, health and well-being of local communities, and which, because of its local character, and the practical difficulties involved, may never be adequately dealt with by Congress. ${ }^{232}$

This extension of the Cooley ${ }^{235}$ rule of concurrent jurisdiction to previously "purely local" activities, with its emphasis on "balancing" "the relative weights of the conflicting local and national interests involved," ${ }^{234}$ would supply the standard mode of analyzing nondiscriminatory state and local regulations for the remainder of the century. ${ }^{2.5}$

281 Parker, 317 US at 362.

282 Id at 362-63 (citations omitted).

283 See text accompanying notes 120-22.

284 Párker, 317 US at 367.

285 See, for example, Pike v Bruce Church, Inc, 397 US 137, 142 (1970) (invalidating state law requiring processing of produce in-state because state interests were outweighed by burden on interstate commerce); Southern Pacific Co v Arizona, 325 US 761, 783 (1945) (holding that the national interest in uniform train regulations outweighs state safety interests in the lengths of 
As for the affirmative Commerce Clause, the relentless pursuit of the logic of realism had, in dialectical fashion, pointed the Court toward a new kind of formalism. If the matter was "economic," Jackson had written, then it was within Congress's power to regulate. The negative pregnant lay dormant for fifty-three years. But when Congress sought to criminalize local possession of a firearm in a school zone, the Lopez majority (almost certainly unwittingly) let fall the other shoe, distinguished "commercial" from "noncommercial" activity, and revived slumbering restraints on the commerce power.

\section{CONCLUSION}

Doctrinal development does not proceed topically; it proceeds synchronically. The Justices of this era did not first decide all of its affirmative Commerce Clause cases, then move on to all of its dormant Commerce Clause cases, and only then to its substantive due process cases. The doctrinal decontextualization involved in the conventional strategy of studying a line of doctrine from its earliest expression through its most recent is thus fundamentally misguided. The anachronism of studying doctrinal development through the categories comprising the modern constitutional sensibility only compounds the error. Such an approach too easily blinds us to the dynamics of interdoctrinal connections and the mechanics of interdoctrinal coordination that characterized the jurisprudence of an earlier age. ${ }^{257}$ Left with such an anemic account of the Justices' intellectual enterprise, we are all the more easily seduced by uncharitable or even cynical and dismissive interpretations of their capacities and motivations. ${ }^{238}$

But such interpretations are too facile. The Court did not enter the Depression decade flanked by two horses saddled and ready to ride. Instead the Justices rode into the 1930 s on one threedimensional jurisprudential steed, which offered different appearances when viewed from various points of vantage: flexibly "realistic" from one angle, unthinkingly "formalistic" from another, but never

trains).

286 United States $v$ Lopez, 514 US 549, 561 (1995) (invalidating as exceeding Congress's commerce power a federal criminal statute having "nothing to do with 'commerce' or any sort of economic enterprise, however broadly one might define those terms").

287 A promising start on a synchronic approach has been made by Paul Brest and Sanford Levinson, Processes of Constitutional Decisionmaking: Cases and Materials (Little, Brown 3d ed 1992), though the authors could do considerably more to identify the sinews that held various doctrines together as a jurisprudential body. For an earlier synchronic presentation with a paucity of connective tissue, see John B. Sholley, Cases on Constitutional Law (Bobbs-Merrill 1951).

288 See Thomas S. Kuhn, The Essential Tension: Selected Studies in Scientific Tradition and Change xii (Chicago 1977) (explaining that scholars should focus on the best or most sensible reading of historical texts).

289 See Corwin, Commerce Power at 167 (cited in note 5). 
fully either. "Formalism" was suffused with "realism," while "realism" was constrained by "formalism."

After Nebbia, however, the center would not hold. The consequences of the Nebbia-Shreveport conjunction, pursued to their logical end, produced the irony that the very embrace of realism led inevitably to its abandonment as a judicial methodology in Commerce Clause cases. For where one's major premise was that every economic activity when aggregated affected commerce substantially, there was no need to undertake a practical, realistic examination of the facts in any particular case. Universal conclusions flowed from universal premises. The Court's decision to abandon judicially-enforced limitations on the commerce power in Wickard v Filburn was thus not simply an election to saddle up young, vigorous Realism rather than old, worn-out Formalism. It was instead a determination to dismount this particular high horse altogether, only to mount another more suited to the spirit of the age.

290 I refer here of course to the heightened solicitude for civil rights and civil liberties both described and heralded in the famous footnote four of United States v Carolene Products Co, 304 US 144,153 n 4 (1938). 